\title{
Impacts of impervious cover, water withdrawals, and climate change on river flows in the conterminous US
}

\author{
P. V. Caldwell, G. Sun, S. G. McNulty, E. C. Cohen, and J. A. Moore Myers \\ USDA Forest Service Eastern Forest Environmental Threat Assessment Center, Raleigh, North Carolina, USA \\ Correspondence to: P. V. Caldwell (pcaldwell02@fs.fed.us)
}

Received: 19 March 2012 - Published in Hydrol. Earth Syst. Sci. Discuss.: 2 April 2012

Revised: 25 July 2012 - Accepted: 28 July 2012 - Published: 21 August 2012

\begin{abstract}
Rivers are essential to aquatic ecosystem and societal sustainability, but are increasingly impacted by water withdrawals, land-use change, and climate change. The relative and cumulative effects of these stressors on continental river flows are relatively unknown. In this study, we used an integrated water balance and flow routing model to evaluate the impacts of impervious cover and water withdrawal on river flow across the conterminous US at the 8-digit Hydrologic Unit Code (HUC) watershed scale. We then estimated the impacts of projected change in withdrawals, impervious cover, and climate under the B1 "Low" and A2 "High" emission scenarios on river flows by 2060. Our results suggest that compared to no impervious cover, 2010 levels of impervious cover increased river flows by $9.9 \%$ on average with larger impacts in and downstream of major metropolitan areas. In contrast, compared to no water withdrawals, 2005 withdrawals decreased river flows by $1.4 \%$ on average with larger impacts in heavily irrigated arid regions of Western US. By 2060, impacts of climate change were predicted to overwhelm the potential gain in river flow due to future changes in impervious cover and add to the potential reduction in river flows from withdrawals, decreasing mean annual river flows from 2010 levels by $16 \%$ on average. However, increases in impervious cover by 2060 may offset the impact of climate change during the growing season in some watersheds. Large water withdrawals will aggravate the predicted impact of climate change on river flows, particularly in the Western US. Predicted ecohydrological impacts of land cover, water withdrawal, and climate change will likely include alteration of the terrestrial water balance, stream channel habitat, riparian and aquatic community structure in snow-dominated basins, and fish and mussel extirpations in heavily impacted watersheds. These changes
\end{abstract}

may also require new infrastructure to support increasing anthropogenic demand for water, relocation of agricultural production, and/or water conservation measures. Given that the impacts of land use, withdrawals and climate may be either additive or offsetting in different magnitudes, integrated and spatially explicit modeling and management approaches are necessary to effectively manage water resources for aquatic life and human use in the face of global change.

\section{Introduction}

River flows are essential for the health of aquatic ecosystems and for anthropogenic water supply. Unfortunately, humans have significantly altered the magnitude and timing of river flows with regulation by dams (Graf, 1999; Poff et al., 2007; Biemans et al., 2011), withdrawals (Gerten et al., 2008), interbasin transfers (Jackson et al., 2001), and land-cover change (Piao et al., 2007). As a result, the health of aquatic ecosystems has declined (Dudgeon et al., 2006; Carlisle et al., 2011; Poff and Zimmerman, 2010), and some water supplies have become stressed (Vörösmarty et al., 2000; Alcamo et al., 2003). In addition to anthropogenic hydrologic alterations, future changes in climate will likely further impact river flows (Bates et al., 2008; Karl et al., 2009).

While water withdrawals may decrease river flows (Gerten et al., 2008; Döll et al., 2009), changes in land cover as a result of deforestation and expanded agriculture (Piao et al., 2007) and urban development (Sun and Lockaby, 2012) generally increase river flows. Part of the increase in flow as a result of urbanization is associated with reductions in evapotranspiration due to the conversion of vegetative land cover from dense natural forests to sparse urban forests and 
grass cover (Lull and Sopper, 1969; O’Driscoll et al., 2010). In addition, impervious cover associated with roads, roof tops, and parking lots generates immediate surface runoff to streams, part of which would have otherwise infiltrated the soil and evapotranspired (Lull and Sopper, 1969). This runoff may convey pollutants to streams, negatively impacting urban aquatic ecosystems (Sun and Lockaby, 2012). Climate change impacts are projected to be highly variable in space, with predicted increases in water yield in some areas and decreases in others (Milly et al., 2008). The complex interactions of human water withdrawals, land-cover change, and climate change are present in most watersheds but remain poorly understood (Sun et al., 2008; Praskievicz and Chang, 2009). There is a clear need for research that examines the combined effects of climate and anthropogenic impacts on river flows over diverse domains.

Several studies have examined the impact of land cover, withdrawals, dams, and/or climate change on water resources over large diverse (regional, continental, or global) domains. These studies have focused on the impact of reservoirs and irrigation withdrawals on river flows (Döll et al., 2009; Wisser et al., 2010; Biemans et al., 2011), impacts of future climate change on runoff (Arnell, 1999; Thompson et al., 2005; Milly et al., 2008), impacts of historic climate change on runoff (McCabe and Wolock, 2010), and impacts of both historic climate change and vegetative land-cover change on runoff (Piao et al., 2007). These studies have largely focused on individual elements of global change (i.e., human water withdrawals, land use, or climate) rather than relative and combined effects, and the impacts of urbanization have been largely left unstudied at this scale.

This study aimed to improve our understanding of combined anthropogenic and climate change impacts on river flows. Specifically, we asked the following questions: (1) what are the individual and combined effects of current levels of impervious cover and water withdrawals on seasonal and mean annual river flows in the conterminous US, and (2) what are the likely impacts of future changes in water withdrawals, impervious cover, and climate change on river flows by 2060 . We achieved our objectives using an enhanced version of the Water Supply Stress Index (WaSSI) integrated monthly water balance and flow routing model (Sun et al., 2008, 2011b; Caldwell et al., 2011), driven by projections of population, impervious cover, and climate under two future emission scenarios. Many new features were added to previous versions of the model, including modeling soil moisture dynamics, channel flow routing, snow melting, and consumptive water use. Model validation was performed using historical long-term flow observations at selected watersheds. Predicted mean annual and monthly mean river flows for 1981-2000 were compared to those of 2041-2060 at the 8-digit Hydrologic Unit Code (HUC) watershed scale.

\section{Methods}

\subsection{Model description}

The WaSSI model has been successfully used in climate change assessments in the Eastern US (Lockaby et al., 2011; Marion et al., 2012) and examining the nexus of water and energy at the national scale (Averyt et al., 2011). WaSSI is an integrated monthly water balance and flow routing model that simulates the full hydrologic cycle for each of 10 land-cover classes in the 2099 Watershed Boundary Dataset (WBD; Watershed Boundary Dataset, 2010) 8-digit Hydrologic Unit Code (HUC) watersheds across the conterminous US (Figs. 1 and 2). The HUC watershed is defined in a national standard, four-level hierarchical system of hydrologic units in the US, ranging from 18 Water Resource Regions (WRR) in the conterminous US at the first level (Table 1) to approximately 2100 Cataloging Units, or HUC watersheds, at the fourth level (Seaber et al., 1987). Hydrologic units in each level are nested within the next higher level, and are assigned a unique code consisting of two or eight digits for WRR and HUC watersheds, respectively.

The model used a conceptual snow model (McCabe and Wolock, 1999; McCabe and Markstrom, 2007) to partition precipitation in each watershed into rainfall and snowfall based on the mean watershed elevation and monthly air temperature, to estimate snow melt rates, and to compute mean monthly snow water equivalent (SWE) over each watershed. Infiltration, surface runoff, soil moisture, and baseflow processes for each HUC watershed land cover were computed in WaSSI using algorithms of the Sacramento Soil Moisture Accounting Model (SAC-SMA) (Burnash et al., 1973; Burnash, 1995). The SAC-SMA model has been used successfully by the National Oceanic and Atmospheric Administration (NOAA) National Weather Service (NWS) for river flood forecasting for decades, and State Soil Geographic Data Base (STATSGO; Natural Resources Conservation Service, 2012) derived SAC-SMA soil input parameters to drive the model have been developed, tested, and made available for the conterminous US (Koren et al., 2003, 2005; Anderson et al., 2006). Monthly evapotranspiration (ET) was modeled with an empirical equation derived from multi-site eddy covariance ET measurements (Sun et al., 2011a,b). Required data to estimate ET included remotely-sensed monthly leaf area index (LAI), Hamon potential ET (PET) calculated as a function of temperature and latitude (Hamon, 1963), and precipitation (PPT). This estimate of ET was then constrained by the soil water content computed by the SAC-SMA algorithm during extreme water-limited conditions. All water balance components were computed independently for each land-cover class within each HUC watershed and accumulated to estimate the totals for the watershed. For the watershed impervious fraction, storage and ET were assumed to be negligible, thus all precipitation falling on the impervious portion of a watershed for a given month was assumed to 
Table 1. Summary of Water Resource Regions (WRR) of the conterminous US.

\begin{tabular}{llcrlll}
\hline WRR & Name & Area & $\begin{array}{r}\text { HUC } \\
\text { watersheds }\end{array}$ & PPT* & $\begin{array}{l}\text { Potential } \\
\text { ET }\end{array}$ & $\begin{array}{l}\text { Actual } \\
\text { ET }\end{array}$ \\
& & $10^{6} \mathrm{~km}^{2}$ & $n$ & $\mathrm{~mm} \mathrm{yr}^{-1}$ & $\mathrm{~mm} \mathrm{yr}^{-1}$ & $\mathrm{~mm} \mathrm{yr}^{-1}$ \\
\hline 01 & New England & 0.18 & 53 & $1141 \pm 79$ & $579 \pm 68$ & $500 \pm 29$ \\
02 & Mid-Atlantic & 0.29 & 94 & $1072 \pm 75$ & $717 \pm 109$ & $593 \pm 110$ \\
03 & South Atlantic-Gulf & 0.72 & 203 & $1362 \pm 142$ & $1041 \pm 118$ & $870 \pm 84$ \\
04 & Great Lakes & 0.30 & 107 & $860 \pm 100$ & $616 \pm 63$ & $475 \pm 38$ \\
05 & Ohio & 0.42 & 120 & $1156 \pm 135$ & $762 \pm 71$ & $583 \pm 52$ \\
06 & Tennessee & 0.11 & 32 & $1447 \pm 150$ & $817 \pm 74$ & $783 \pm 46$ \\
07 & Upper Mississippi & 0.49 & 131 & $851 \pm 126$ & $691 \pm 83$ & $559 \pm 64$ \\
08 & Lower Mississippi & 0.27 & 82 & $1449 \pm 99$ & $1035 \pm 81$ & $880 \pm 100$ \\
09 & Souris-Red-Rainy & 0.15 & 42 & $517 \pm 79$ & $576 \pm 29$ & $433 \pm 35$ \\
10 & Missouri & 1.32 & 309 & $559 \pm 235$ & $650 \pm 115$ & $438 \pm 110$ \\
11 & Arkansas-White-Red & 0.64 & 173 & $827 \pm 338$ & $901 \pm 119$ & $611 \pm 154$ \\
12 & Texas-Gulf & 0.47 & 122 & $814 \pm 279$ & $1122 \pm 99$ & $644 \pm 152$ \\
13 & Rio Grande & 0.34 & 70 & $364 \pm 90$ & $876 \pm 234$ & $349 \pm 57$ \\
14 & Upper Colorado & 0.29 & 61 & $412 \pm 163$ & $552 \pm 120$ & $319 \pm 54$ \\
15 & Lower Colorado & 0.36 & 85 & $326 \pm 120$ & $911 \pm 232$ & $309 \pm 89$ \\
16 & Great Basin & 0.37 & 71 & $368 \pm 170$ & $597 \pm 86$ & $310 \pm 83$ \\
17 & Pacific Northwest & 0.71 & 218 & $1024 \pm 708$ & $536 \pm 77$ & $500 \pm 185$ \\
18 & California & 0.42 & 126 & $734 \pm 476$ & $751 \pm 162$ & $419 \pm 151$ \\
\hline
\end{tabular}

* Mean \pm standard deviation across all HUC watersheds in each WRR over the period 1981-2000 based on WaSSI simulations using the CM2.0 general circulation model climate estimates.

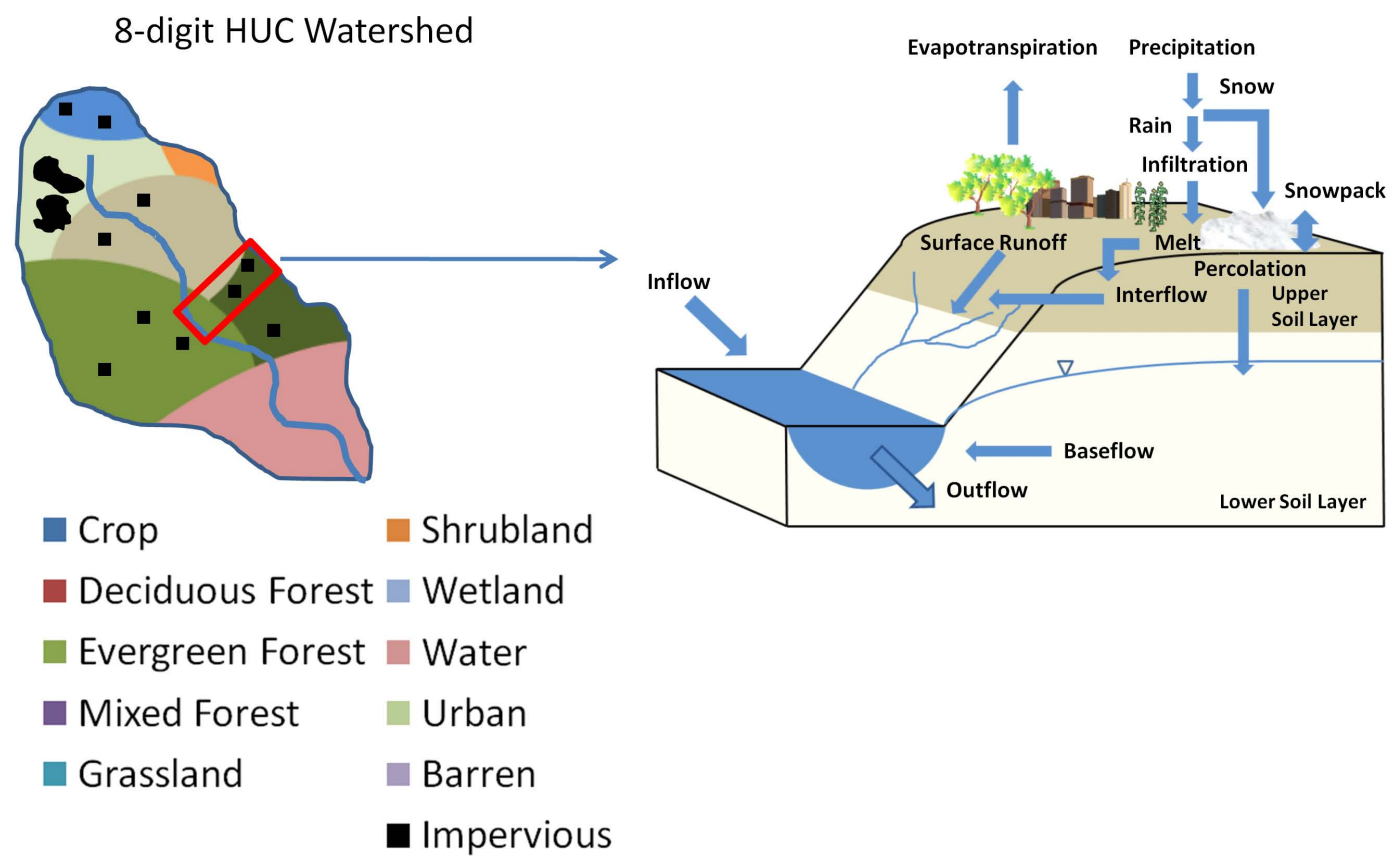

Fig. 1. Hydrologic processes in the WaSSI water balance model.

generate surface runoff in the same month, and was routed directly to the watershed outlet.

The connectivity and flow accumulation of the 8-digit HUC watershed river network was estimated by overlaying the National Hydrography Dataset (NHD; National
Hydrography Dataset, 2010) flow lines on to the WBD 8digit HUC boundaries. No interbasin transfers (i.e., canals aquaducts, pipelines, etc.) or water storage reservoirs were included in the flow network because these features are not completely represented in NHD and their flows are 


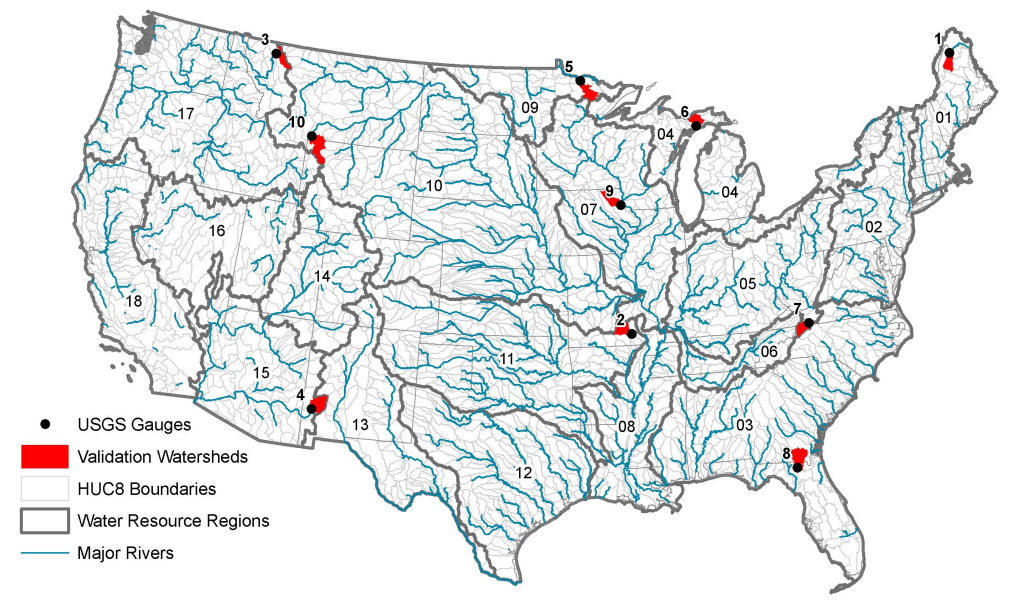

Fig. 2. Model validation watersheds, validation sites, Water Resource Regions, and 8-digit HUC (HUC8) boundaries of the conterminous US. Numbers 01 through 18 identify locations of Water Resource Regions.

intensively managed with very little data available at the conterminous US scale. However, net monthly populationadjusted anthropogenic surface water withdrawals were computed as the total water withdrawals minus total groundwater withdrawals minus return flows, and were subtracted from the accumulated flow at the outlet of each watershed. It was assumed that all return flows, regardless of whether they originated from surface or groundwater, were discharged to surface water at the inlet of the next downstream watershed. In months where net surface water withdrawals exceeded river flow at a watershed outlet, flow was set to zero and the remaining water demand was assumed to be supplied by an infinite water supply reservoir (e.g., deep water well). All water in the flow network was assumed to be routed in the same month it was generated, and in-stream flow losses to deep groundwater were assumed to be negligible.

\subsection{Model validation}

The WaSSI predictions for the watershed water balance and runoff were validated using monthly observed runoff measurements between 1961 and 2007 at the outlets of 10 representative watersheds across the US (Fig. 2). The intention of the model validation was to demonstrate the ability of the model to capture the temporal and spatial variability of the natural water balance, e.g., evapotranspiration, snow accumulation and melt, and runoff processes. The sites are part of the US Geological Survey (USGS) Hydro-Climatic Data Network (HCDN), a subset of USGS gauges without significant upstream flow regulation (dams) or diversions to other watersheds (interbasin transfers) (Slack et al., 1993). It would not have been appropriate to validate WaSSI in watersheds with dams or diversions because these are not currently represented in the model. Impervious cover was included in the model simulations of the validation sites, but surface water withdrawals were not included because the resolution of national water use estimates are too coarse for site-level evaluation and the water intakes and outfalls are not referenced to specific locations on river reaches. As a result it is not known whether a streamflow gauge is upstream of all water intakes in the upstream watershed (no withdrawal impact on streamflow), downstream of the intake but upstream of the outfall (maximum withdrawal impact on streamflow), or downstream of both the intakes and the outfalls (streamflow impacted by consumptive water use). Mean annual bias, annual correlation, and monthly correlation between the observed and predicted runoff for these sites were compared to test the ability of WaSSI to reproduce historic runoff measurements. No calibration of model input parameters was performed during the model validation process. WaSSI was developed to include the key ecohydrological processes that affect the water balance with off-the-shelf input datasets while having an acceptable level of predictive performance across the conterminous US without calibration. In doing so, the model is more robust when expanding the model domain to other basins not included in the model calibration process and using the model to assess the impact of climate or land-cover scenarios outside of the conditions for which the model is calibrated.

\section{$2.3 \quad$ Future scenarios}

For prediction of future river flows by mid-century, the Intergovernmental Panel on Climate Change (IPCC) Special Report on Emissions Scenarios (SRES) (Nakicenovic and Swart, 2000) A2 and B1 storylines were selected to represent high and low growth and emission scenarios, respectively. The SRES characterized the A2 storyline (hereafter "High") as a very heterogeneous world with continuously increasing global population and regionally-oriented economic growth with relatively slow technological change. In contrast, the B1 storyline (hereafter "Low") was characterized 
as a convergent world with a global population that peaks around mid-century, rapid changes in economic structures toward a service and information economy, reductions in material intensity, and the introduction of clean and resourceefficient technologies. In addition to the water resource impacts by climate change as a result of greenhouse gas emissions, these scenarios have implications for water resources due to increased urbanization and associated impervious cover as well as changes in water withdrawals as population increases overall and becomes more concentrated in urbanizing watersheds.

The objective of this study was to quantify the longterm mean impacts of changes in climate, land use, and water withdrawals on stream flow around the middle of the 21 st century as compared to a baseline historical time period, under the High and Low scenarios. Twenty-year time periods for both was considered to be sufficiently long to isolate the long-term impacts with minimal influence from extreme events that may significantly influence results when evaluating a shorter time period. The 1981-2000 time period was selected as the baseline because both the A2 and B1 realizations of the CM2.0 ( Coupled model version 2.0) general circulation model were run with the same 20C3M (20th Century Climate in Coupled Models) atmospheric greenhouse gas concentrations prior to 2000 and thus had identical monthly time-series of PPT and temperature estimates with which to provide a common baseline. While a more recent time period such as 1991-2010 may be more representative of current conditions and align more closely to the water withdrawal and land-cover inputs, the A2 and B1 realizations of the CM2.0 PPT and temperature estimates already diverge by 2010 , so there is not a common baseline. The 2041-2060 future time period was selected because it brackets the year 2050, mid-21st century.

Impacts of existing impervious cover and net surface water withdrawals on historic river flows at the outlets of all 2099 8-digit HUC watersheds were estimated by comparing predicted 1981-2000 monthly and mean annual river flows both with and without 2010 levels of impervious cover and surface water withdrawals. Impacts of projected changes in impervious cover, surface water withdrawals, and climate change under the High and Low scenarios were estimated by comparing predicted 2041-2060 river flows with 2060 levels of impervious cover and withdrawals to those of 1981-2000 with 2010 levels of impervious cover and withdrawals.

\subsection{Databases}

The WaSSI model framework was designed to be highly transferable and to require minimal input data for regional applications. Required input data were readily available for the conterminous US in a grid or county format at a variety of spatial resolutions (Table 2). All input data were rescaled from their native gridded or county resolution to the 8-digit HUC watershed scale for use in the WaSSI model.

\subsubsection{Vegetation and soil parameterization}

The 17 land-cover categories of the 2006 National Land Cover Dataset (NLCD) (Fry el al., 2011) were aggregated to 10 classes: crop, deciduous forest, evergreen forest, mixed forest, grassland, shrubland, wetland, water, urban, and barren (Fig. 1). For this study, the distribution of these classes was assumed to remain constant over time, although the amount of impervious cover within each landcover class varied over time. A gap-filled version of the Moderate Resolution Imaging Spectroradiometer (MODIS) MOD15A2 FPAR/LAI 8-day composite (Zhao et al., 2005) was averaged to monthly mean LAI between years 2000 and 2006 and was overlaid by the land-cover data to obtain monthly mean LAI by land cover within each HUC watershed for ET calculations. Like the land-cover distribution, monthly mean LAI for each land cover was assumed to remain constant over time. The SAC-SMA soil parameter grids were obtained from the NOAA NWS Hydrology Laboratory, Office of Hydrologic Development, and mean watershed elevation was computed from the HYDRO1k Elevation Derivative Database (Verdin, 2011).

\subsubsection{Climate}

For model validation, monthly observed precipitation and temperature data from 1961 to 2007 (PRISM Climate Group, 2010) were used. This dataset was developed based on historic weather observations using the Precipitation Elevation Regression on Independent Slopes Model (Daly et al., 1994). For evaluation of the impact of climate change on river flows, statistically downscaled $1 / 8 \times 1 / 8^{\circ}(\sim 12 \times 12 \mathrm{~km}) 1981$ 2060 monthly precipitation and temperature predicted by NOAA's Geophysical Fluid Dynamics Laboratory coupled climate model CM2.0 for the A2 and B1 emission scenarios were obtained from the World Climate Research Programme Coupled Model Intercomparison Project Phase 3 dataset (Meehl et al., 2007).

\subsubsection{Impervious cover}

The 2006 NLCD fraction impervious layer was used to compute the fraction of each of the ten land-cover classes with impervious cover for model validation. We incorporated the impervious cover predictions from the US Environmental Protection Agency (EPA) Integrated Climate and Land Use Scenarios (ICLUS) project (US Environmental Protection Agency, 2009; Bierwagen et al., 2010) linked to the main storylines of the SRES for assessment of changes in impervious cover on river flows. These land-cover predictions used demographic and spatial allocation modeling to create scenarios of housing density changes with national coverage at $1 \times 1 \mathrm{~km}$ resolution from 2010 to 2100 based on past landuse patterns and travel time along roads from urban areas. We applied the 2010 impervious cover fraction to the urban 
Table 2. Model databases.

\begin{tabular}{|c|c|c|c|}
\hline Database & Source & $\begin{array}{l}\text { Native } \\
\text { resolution }\end{array}$ & $\begin{array}{l}\text { Time } \\
\operatorname{period}(s)\end{array}$ \\
\hline Soil Properties & $\begin{array}{l}\text { STATSGO-based Sacramento Soil Moisture Accounting } \\
\text { Model Soil Parameters and NOAA-NWS Hydrology } \\
\text { Laboratory, Office of Hydrologic Development }\end{array}$ & $1 \times 1 \mathrm{~km}$ & N/A \\
\hline $\begin{array}{l}\text { Land-cover } \\
\text { Distribution }\end{array}$ & $\begin{array}{l}2006 \text { National Land Cover Database for the Conterminous } \\
\text { US (http://www.mrlc.gov/nlcd06_data.php) }\end{array}$ & $30 \times 30 \mathrm{~m}$ & 2006 \\
\hline $\begin{array}{l}\text { Leaf Area Index } \\
\text { by Land Cover }\end{array}$ & $\begin{array}{l}\text { Moderate Resolution Imaging Spectroradiometer (MODIS) } \\
\text { (http://modis.gsfc.nasa.gov/) }\end{array}$ & $1 \times 1 \mathrm{~km}$ & 2000-2006 \\
\hline $\begin{array}{l}\text { Mean Watershed } \\
\text { Elevation }\end{array}$ & $\begin{array}{l}\text { USGS National Elevation Dataset } \\
\text { (http://eros.usgs.gov/) }\end{array}$ & $30 \times 30 \mathrm{~m}$ & N/A \\
\hline $\begin{array}{l}\text { Total } \\
\text { Withdrawals }\end{array}$ & $\begin{array}{l}\text { USGS Estimated Use of Water in the US in } 2005 \\
\text { (http://pubs.usgs.gov/circ/1344/) }\end{array}$ & County & $2005^{*}$ \\
\hline $\begin{array}{l}\text { Groundwater } \\
\text { Withdrawals }\end{array}$ & $\begin{array}{l}\text { USGS Estimated Use of Water in the US in } 2005 \\
\text { (http://pubs.usgs.gov/circ/1344/) }\end{array}$ & County & 2005 \\
\hline $\begin{array}{l}\text { Return Flow } \\
\text { Percentage }\end{array}$ & $\begin{array}{l}\text { USGS Estimated Use of Water in the US in } 1995 \\
\text { (http://water.usgs.gov/watuse/pdf1995/html/) }\end{array}$ & County & 1995 \\
\hline $\begin{array}{l}\text { Observed } \\
\text { Streamflow } \\
\text { (Model Validation) }\end{array}$ & $\begin{array}{l}\text { USGS National Water Information System } \\
\text { (http://waterdata.usgs.gov/nwis/) }\end{array}$ & N/A & 1961-2007 \\
\hline $\begin{array}{l}\text { Climate } \\
\text { (Model Validation) }\end{array}$ & $\begin{array}{l}\text { PRISM Climate Group } \\
\text { (http://prism.oregonstate.edu/) }\end{array}$ & $4 \times 4 \mathrm{~km}$ & 1961-2007 \\
\hline $\begin{array}{l}\text { Climate } \\
\text { (A2, B1 scenarios) }\end{array}$ & $\begin{array}{l}\text { Downscaled GFDL CM2.0, A2 and B1 scenarios, World } \\
\text { Climate Research Programme CMIP3 dataset } \\
\text { (http://www-pcmdi.llnl.gov/ipcc/about_ipcc.php) }\end{array}$ & $12 \times 12 \mathrm{~km}$ & $1981-2060$ \\
\hline $\begin{array}{l}\text { Impervious Cover } \\
\text { (A2, B1 scenarios) }\end{array}$ & $\begin{array}{l}\text { US EPA ICLUS Project } \\
\text { (http://www.epa.gov/ncea/global/index.htm) }\end{array}$ & $1 \times 1 \mathrm{~km}$ & 2010,2060 \\
\hline $\begin{array}{l}\text { Projected Population } \\
\text { (A2, B1 scenarios) }\end{array}$ & $\begin{array}{l}\text { US EPA ICLUS Project } \\
\text { (http://www.epa.gov/ncea/global/index.htm) }\end{array}$ & County & 2010,2060 \\
\hline
\end{tabular}

* Domestic sector water use for future scenarios adjusted for population to represent 2060 domestic water use.

land-cover class in each watershed for the baseline 2010 scenario. For the future scenarios, the change in impervious cover fraction between 2010 and 2060 for the High and Low scenarios was assumed to come equally from the crop, deciduous forest, evergreen forest, mixed forest, grassland, and shrubland land-cover classes in each watershed (where present).

\subsubsection{Net surface water withdrawals}

The 2005 USGS county-level annual total water withdrawal and groundwater withdrawal estimates (Kenny et al., 2009) were used to estimate withdrawals for the domestic, industrial, irrigation, mining, thermopower, livestock, public supply, and aquaculture sectors. These data were disaggregated to the monthly scale using regional regression relationships based on water use data collected at the state level. Return flow percentages by sector were computed using consumptive use estimates from the 1995 USGS water use report (Solley et al., 1998).

Total water use for all sectors in the US steadily increased from 1950-1980 (Kenny et al., 2009). Since that time, water use for the irrigation, livestock, mining, and thermopower sectors has remained relatively constant; industrial water use has decreased; and domestic, public supply, and aquaculture sector water use have increased (Kenny et al., 2009). For this study, we assumed that water use from all sectors remained at year 2005 levels in 2010. Further, we assumed that water use from all sectors, with the exception of domestic and the portion of public supply serving domestic water use, remained at 2005 levels from 2010 to 2060 . The 2010 and 2060 decadal population estimates for the High and Low scenarios provided by the EPA ICLUS project (US Environmental Protection Agency, 2009; Bierwagen et al., 2010) were used to 

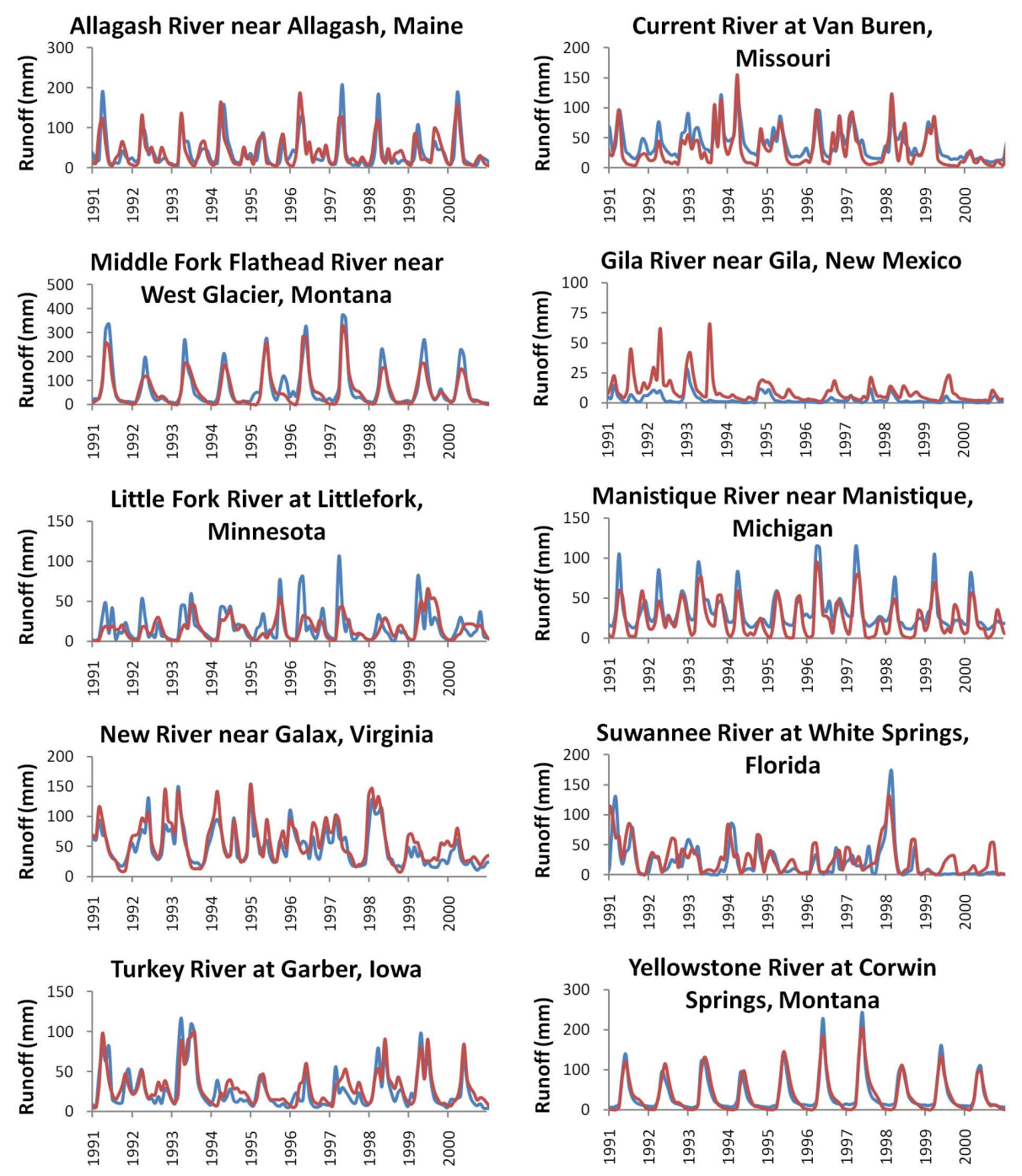

Fig. 3. Time series of observed (blue) and predicted (red) 1991-2000 monthly runoff for the 10 validation watersheds.

adjust the domestic and the portion of public supply serving domestic uses for population growth by 2060. Per capita water use rates were estimated for each HUC watershed based on 2010 population (US Environmental Protection Agency, 2009; Bierwagen et al., 2010) coupled with 2005 domestic and public supply serving domestic water use (Kenny et al., 2009). The computed per capita rates for domestic water use were assumed to remain constant over time. Groundwater withdrawals for all sectors were assumed to remain at 2005 levels, thus the additional water demand for the domestic and public supply sectors was supplied only by surface water sources.

\section{Results}

\subsection{Model validation}

The WaSSI model performed well in representing the annual and monthly runoff patterns at the ten validation sites (Table 3, Fig. 3). Correlations between both annual and monthly observed and predicted runoff were all significant $(P<0.01)$, indicating that the model successfully captured the temporal variability in monthly runoff at these sites. Bias in mean annual runoff prediction was within $20 \%$ at most sites, but model predictions at some sites had relatively high bias (e.g., the Gila River near Gila, New Mexico, and the Turkey River at Garber, Iowa). Errors in runoff predicted by the WaSSI model may be attributed to uncertainty in input data (e.g., climate and soil properties), as well as uncertainty in the simplified representation of the physical processes that govern runoff magnitude and timing. For example, the large 
(a)

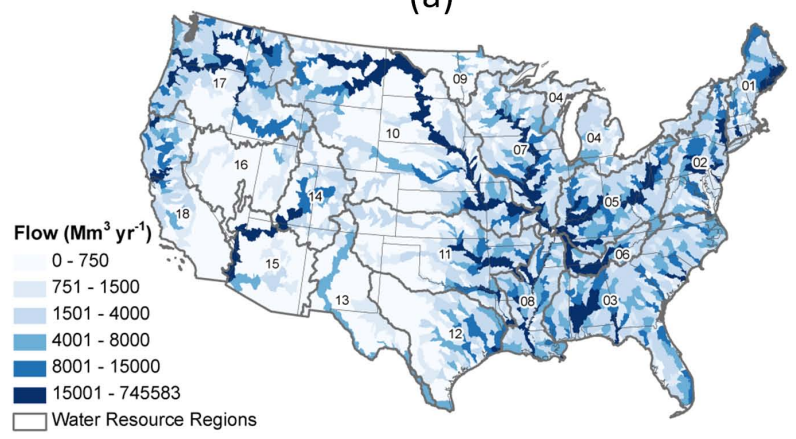

(c)

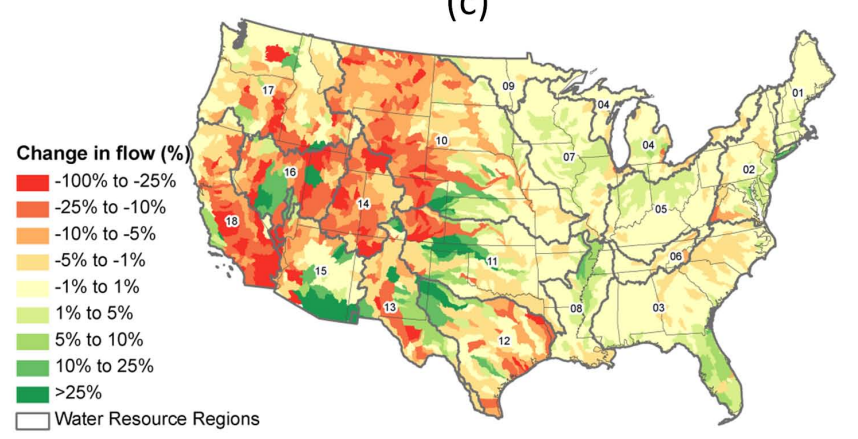

(b)

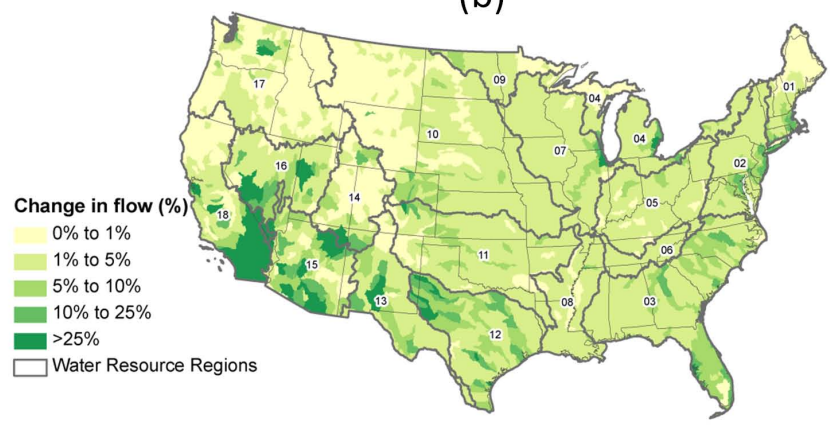

(d)

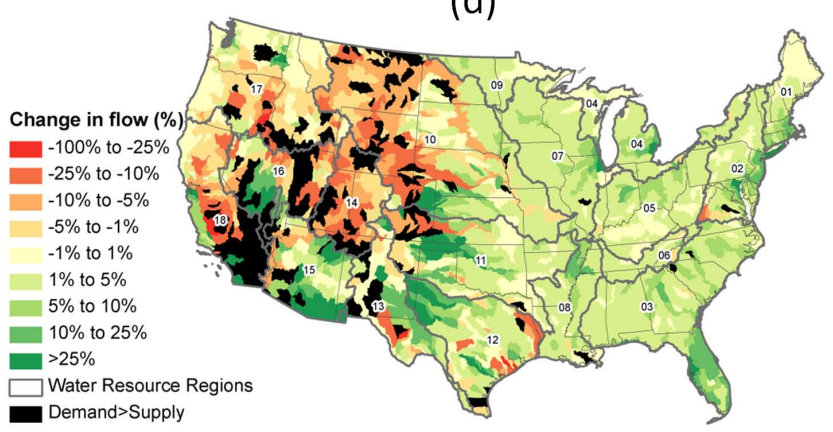

Fig. 4. 1981-2000 mean annual flow $\left(\mathrm{Mm}^{3} \mathrm{yr}^{-1}\right)$ assuming no net surface water withdrawals and no impervious cover (a), and change in mean annual flow due to 2010 impervious cover (b), 2005 withdrawals (c), and both 2010 impervious cover and 2005 withdrawals (d). Gross demand in black areas in (d) is greater than the sum of surface water supply and groundwater withdrawals, indicating likely transfer of water from other watersheds.

positive model bias (i.e., model over predicted flow rates relative to measured values) for the Gila River, a watershed located in arid New Mexico receiving approximately $510 \mathrm{~mm}$ of precipitation annually, may be associated with terrestrial or instream losses to deep groundwater. The moderate positive bias for the Turkey River at Garber, Iowa, a watershed comprised of $71 \%$ crop land cover, much of which is irrigated, may be associated with the underestimation of ET for irrigated crops. Flow regulation by dams and diversions to other watersheds were also not represented in the model, but may exist even in watersheds upstream of these relatively unaltered sites. Despite the differences between observed and predicted runoff at some sites, the WaSSI model captured the temporal and spatial variability in runoff, with performance that was comparable to other uncalibrated continental-scale monthly water balance models used for global change impact assessment (e.g., McCabe and Wolock, 2010).

\subsection{Impervious cover and withdrawal impacts on 1981-2000 river flows}

The impacts of 2010 levels of impervious cover and 2005 water withdrawals on mean annual and monthly mean 19812000 river flows were evaluated by comparing the following scenarios to the 1981-2000 river flows without impervious cover or withdrawals baseline case: (1) 2010 impervious cover and no withdrawals, (2) no impervious cover and 2005 withdrawals, and (3) 2010 impervious cover and 2005 withdrawals.

\subsubsection{River flows without impervious cover or withdrawals}

The 8-digit HUC watershed river network was apparent in the spatial variability of predicted 1981-2000 mean annual river flows (Fig. 4a), reflecting the influence of both climate regime and drainage area. The mean annual river flow, averaged across all HUC watersheds in each Water Resource Region (WRR), ranged from $480 \mathrm{Mm}^{3} \mathrm{yr}^{-1}$ to $32000 \mathrm{Mm}^{3} \mathrm{yr}^{-1}$, and was highest in WRR $08,06,05$, and 07 (Fig. 5) due to the cumulative effects of drainage area, PPT, and ET (Table 1). For example, WRR 06 had the smallest drainage area of all WRR, but had the second highest mean annual flow because the mean annual PPT in this WRR (1447 mm) was higher than all other regions except 08 , and watersheds in this region had the second lowest ET/PPT ratios (0.52) among all WRR. In contrast, WRR 07 had a much larger drainage area, but had a lower mean annual 
Table 3. Model validation results for 10 representative watersheds 1961-2007.

\begin{tabular}{|c|c|c|c|c|c|c|c|c|c|}
\hline & \multirow{3}{*}{ Site } & \multirow{3}{*}{$\begin{array}{l}\text { USGS } \\
\text { gauge }\end{array}$} & \multirow{3}{*}{$\begin{array}{c}\text { Drainage } \\
\text { area }\end{array}$} & \multicolumn{4}{|c|}{ Mean annual runoff } & \multicolumn{2}{|c|}{ Predicted vs. observed $R^{2}$} \\
\hline & & & & \multirow{2}{*}{$\begin{array}{l}\text { Observed } \\
\mathrm{mm}\end{array}$} & \multirow{2}{*}{$\begin{array}{c}\text { Predicted } \\
\mathrm{mm}\end{array}$} & \multicolumn{2}{|c|}{ Model bias } & \multirow[t]{2}{*}{ Annual } & \multirow[t]{2}{*}{ Monthly } \\
\hline & & & & & & $\mathrm{mm}$ & $\%$ & & \\
\hline 1 & Allagash River near Allagash, Maine & 01011000 & 3828 & 463 & 468 & 5 & $1 \%$ & 0.81 & 0.44 \\
\hline 2 & Current River at Van Buren, Missouri & 07067000 & 4318 & 421 & 353 & -68 & $-16 \%$ & 0.76 & 0.73 \\
\hline 3 & $\begin{array}{l}\text { Middle Fork Flathead River near West Glacier, } \\
\text { Montana }\end{array}$ & 12358500 & 2922 & 873 & 726 & -148 & $-17 \%$ & 0.78 & 0.87 \\
\hline 4 & Gila River near Gila, New Mexico & 09430500 & 4828 & 33 & 100 & 67 & $200 \%$ & 0.65 & 0.40 \\
\hline 5 & Little Fork River at Littlefork, Minnesota & 05131500 & 4351 & 233 & 193 & -39 & $-17 \%$ & 0.74 & 0.52 \\
\hline 6 & Manistique River near Manistique, Michigan & 04056500 & 2849 & 449 & 341 & -108 & $-24 \%$ & 0.74 & 0.74 \\
\hline 7 & New River near Galax, Virginia & 03164000 & 2955 & 587 & 674 & 87 & $15 \%$ & 0.87 & 0.82 \\
\hline 8 & Suwannee River at White Springs, Florida & 02315500 & 6294 & 255 & 317 & 62 & $24 \%$ & 0.87 & 0.62 \\
\hline 9 & Turkey River at Garber, Iowa & 05412500 & 4002 & 256 & 320 & 64 & $25 \%$ & 0.83 & 0.54 \\
\hline 10 & Yellowstone River at Corwin Springs, Montana & 06191500 & 6783 & 418 & 428 & 10 & $2 \%$ & 0.76 & 0.88 \\
\hline
\end{tabular}

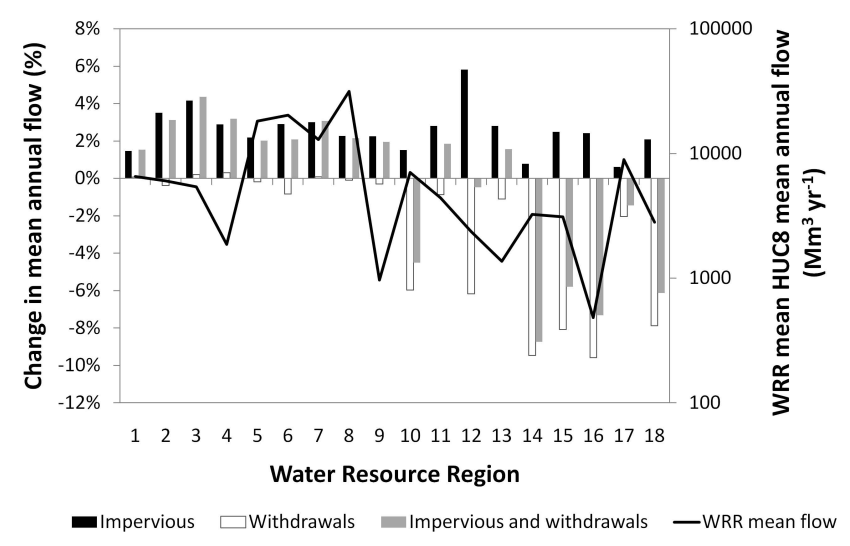

Fig. 5. Mean annual flow without impervious cover or withdrawals, and impacts of 2010 impervious cover and 2005 withdrawals on 1981-2000 mean annual flow, averaged over all 8-digit HUC watersheds in each Water Resource Region.

river flow than WRR 06 because watersheds in this region and WRR 10 draining into it had lower mean annual PPT (851 $\mathrm{mm}$ and $559 \mathrm{~mm}$, respectively) and higher ET/PPT ratios ( 0.67 and 0.84 , for WRR 07 and 10, respectively). The top five predicted mean annual river flows by WRR included the WRR 08 - Lower Mississippi River $\left(746000 \mathrm{Mm}^{3} \mathrm{yr}^{-1}\right.$ ), WRR 05 - Ohio River $\left(304000 \mathrm{Mm}^{3} \mathrm{yr}^{-1}\right.$ ), WRR 07 - Upper Mississippi River $\left(280000 \mathrm{Mm}^{3} \mathrm{yr}^{-1}\right)$, WRR 17 - Lower Columbia River $\left(166000 \mathrm{Mm}^{3} \mathrm{yr}^{-1}\right)$, and WRR $10-$ Missouri River $\left(142000 \mathrm{Mm}^{3} \mathrm{yr}^{-1}\right)$.

\subsubsection{Impact of 2010 impervious cover}

In 2010, approximately $102100 \mathrm{~km}^{2}$ of area across the 2099 HUC watersheds of the conterminous US were classified as impervious $(1.3 \%$ of the total land area; roughly the size of the state of Virginia), and were concentrated in major population centers. HUC watershed fraction impervious cover ranged from $0.01 \%$ in the Upper Selway basin (HUC 17060301), Idaho, to $40 \%$ in the Bronx basin (HUC 02030102), New York. The area-weighted mean impervious cover fraction across all watersheds was $1.3 \%$.

2010 levels of impervious cover generally resulted in small increases in HUC watershed 1981-2000 mean annual river flows (mean $9.9 \%$, median $2.2 \%, n=2099$ ) compared to 1981-2000 flows without impervious cover (Fig. 4b), with 480 of the 2099 HUC watersheds (23\% of land area) predicted to have less than $1 \%$ increases in mean annual flow. River flows in the arid Southwest region were most sensitive to impervious cover on a relative basis, but given the low flows of this region, absolute increases in flow were small. Impervious cover in highly urbanized areas of the East led to large relative and absolute changes in river flows. For example, the mean annual flow in HUC 07120004 - Des Plaines River draining part of the Chicago, Illinois metropolitan area (18\% impervious) increased from $1899 \mathrm{Mm}^{3} \mathrm{yr}^{-1}$ to $2544 \mathrm{Mm}^{3} \mathrm{yr}^{-1}$ as a result of impervious cover, a $35 \%$ increase $\left(655 \mathrm{Mm}^{3} \mathrm{yr}^{-1}\right)$. The impact of the impervious cover associated with the city of Chicago resulted in $5-10 \%$ increases in mean annual flows in downstream HUC watersheds along the Illinois River until the confluence with the Mississippi River in WRR 07 (Fig. 4b). Increases in mean annual flow as a result of impervious cover, averaged over all HUC watersheds in each WRR, were generally less than $5 \%$ (Fig. 5), ranging from less than $1 \%$ in WRR 17 to $5.8 \%$ in WRR 12.

\subsubsection{Impact of 2005 net surface water withdrawals}

In 2005, total estimated water withdrawals in the conterminous US were approximately $483000 \mathrm{Mm}^{3} \mathrm{yr}^{-1}$. Groundwater supplied approximately $23 \%$ of the total water demand, and was most heavily used in the Western US for irrigation, supplying approximately $41 \%$ of irrigation water demand in this region (Kenny et al., 2009). In the Eastern US 
(WRR 01-07), the thermopower sector was the largest gross water use sector, representing $69 \%$ of the total water use in this region. However, return flow rates from the thermopower sector were generally very high ( $95 \%$ on average), so much of that water was returned to surface water. In the Western US (WRR 08-18), irrigation was the largest gross water use sector ( $65 \%$ of the total water use), but return flow rates were much lower (39\%). Across the US, domestic and public supply water use serving the domestic sector was highest in HUC watersheds supporting urban population centers.

The net surface water withdrawals in each HUC watershed were computed as the total withdrawal - groundwater withdrawals - return flows from all water use sectors. Depending on the relative withdrawals of surface water and groundwater, and the total return flow in a HUC watershed, the net surface water withdrawal as defined above may be positive (water removed from river flow) or negative (water added to river flow). Because we assumed that all return flows were discharged to surface water regardless of whether the water came from ground or surface water sources, accounting for these withdrawals increased river flows if the groundwater fraction of the total withdrawals (GWF) was greater than 1 minus return flow fraction (1-RFF) across all water use sectors in a given watershed. For example, total withdrawals in HUC 11010013 - Upper White-Village were $456 \mathrm{Mm}^{3} \mathrm{yr}^{-1}$, groundwater withdrawals were $398 \mathrm{Mm}^{3} \mathrm{yr}^{-1}$, and the net RFF was 0.28 . Thus, GWF (0.87) was greater than $1-$ RFF (0.73), resulting in a net surface water withdrawal of $-67 \mathrm{Mm}^{3} \mathrm{yr}^{-1}$ (water added to river flow). In contrast, total withdrawals in adjacent HUC 11010004 - Middle White were $98 \mathrm{Mm}^{3} \mathrm{yr}^{-1}$, groundwater withdrawals were $39 \mathrm{Mm}^{3} \mathrm{yr}^{-1}$, and the net RFF was 0.55 . In this case, GWF (0.40) was less than $1-$ RFF (0.45), resulting in a net surface water withdrawal of $+4.9 \mathrm{Mm}^{3} \mathrm{yr}^{-1}$ (water removed from river flow).

Changes in mean annual river flows due to withdrawals across the conterminous US were within $5 \%$ in $1490(71 \%)$ of the 2099 HUC watersheds compared to flows without withdrawals (Fig. 4c). The impact of high GWF relative to $1-$ RFF resulting in increases in river flows due to withdrawals was evident in the groundwater irrigated areas of the upper Midwest (WRR 07), Mississippi Alluvial Valley (WRR 08), portions of coastal WRR 03, and the southern Great Plains (WRR 11 and 12). Mean annual river flows were predicted to have decreased as a result of withdrawals in much of WRR 10-18, excluding the southern Great Plains region. Thirty-four HUC watersheds (all located in WRR 10, $11,14,15,16,17$, and 18) were predicted to have mean annual flows decrease by $50 \%$ or more as a result of withdrawals, and seven of these watersheds were predicted to have river flows decrease by $100 \%$ (all in southern WRR 18 and WRR 15). While perhaps decreases in river flows of this magnitude as a result of withdrawals are possible, these large relative changes in river flows are likely a result of uncertainty in the withdrawal estimates and/or the lack of representation of interbasin transfers in this study. Most of these watersheds had very low predicted mean annual flow without withdrawals (less than $70 \mathrm{Mm}^{3} \mathrm{yr}^{-1}$ ); thus, uncertainty in withdrawal estimates may be large relative to river flows, leading to unrealistic withdrawal impacts. The average changes in mean annual flow by WRR as a result of withdrawals were within $1 \%$ in WRR 01-09, which is smaller than the impact of impervious cover in these regions (Fig. 5). However, withdrawals were projected to decrease WRR mean annual river flows in WRR 10-18, ranging from decreases of $0.9 \%$ (WRR 11) to $9.6 \%$ (WRR 14).

\subsubsection{Combined impacts of 2010 impervious cover and 2005 withdrawals}

The combined effects of impervious cover and net surface water withdrawals on 1981-2000 mean annual river flows generally resulted in flow increases in the Eastern US (WRR 01-09) and flow decreases in the Western US (WRR 10-18) compared to 1981-2000 flows without impervious cover or withdrawals (Figs. $4 \mathrm{~d}$ and 5). The flow increases in the East were largely driven by the flow increases due to impervious cover (Fig. 5), and to a lesser extent, where GWF was greater than $1-$ RFF, by net surface water withdrawals that increased river flows. The increase in river flows as a result of impervious cover in much of the West was offset by the decreases in river flows as a result of withdrawals. Under the combined effects of impervious cover and withdrawals, the average change in mean annual river flows by WRR were increases of $1.5 \%$ to $4.4 \%$ in WRR 01-09 and decreases up to $8.8 \%$ in WRR 10-18. In 186 HUC watersheds (primarily in the arid Southwest), the mean annual ratio of total withdrawals to total supply from surface and groundwater sources exceeded 1.0 (Fig. 4d). In part this may be related to uncertainty in water use and/or supply estimates, but may also indicate that these watersheds receive water from other basins by interbasin transfer.

\subsubsection{Case studies}

Two HUC watersheds of contrasting climate, land cover, and water withdrawals were selected to illustrate the annual and seasonal impacts of 2010 levels of impervious cover and 2005 withdrawals on 1981-2000 river flows. The HUC watershed 03130001 - Upper Chattahoochee River is a headwater watershed that provides much of the water supply for the Atlanta, GA metropolitan area. The watershed was $49 \%$ forested, with impervious cover comprising $10 \%$ of the watershed area. Net surface water withdrawals were $49 \mathrm{Mm}^{3} \mathrm{yr}^{-1}$, or $1.6 \%$ of mean annual flow without impervious cover or withdrawals. River flow from this watershed was greatest during the winter months (Fig. 6a), driven primarily by the seasonal pattern of ET and to a lesser extent the pattern of PPT. While impervious cover increased mean annual flow by $11.1 \%\left(327 \mathrm{Mm}^{3} \mathrm{yr}^{-1}\right)$, this increase was largest in 
(a)
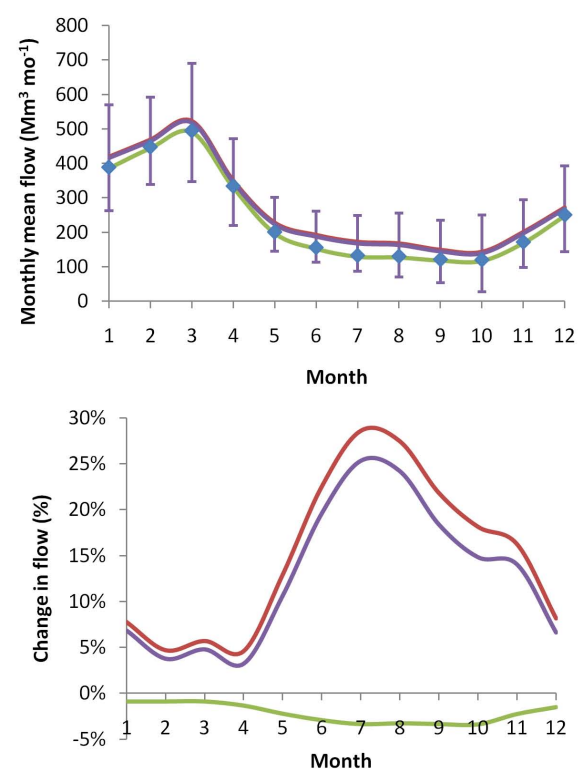

(b)
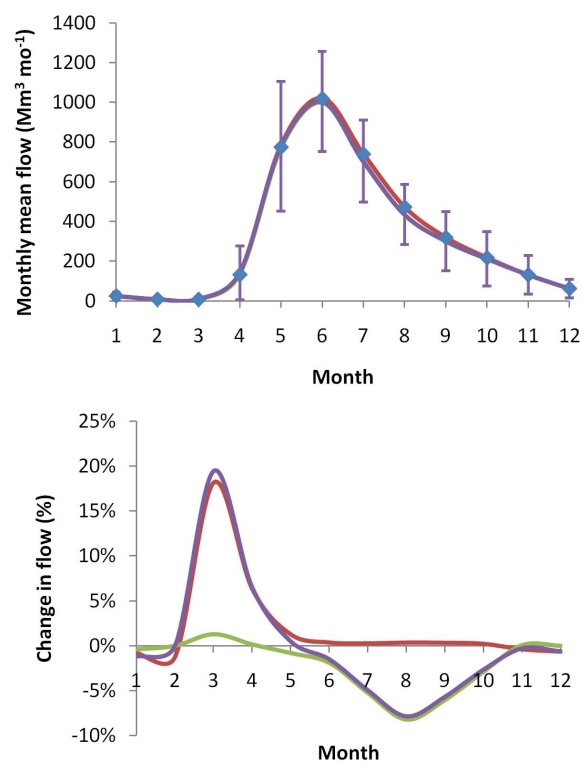

Fig. 6. Impacts of 2010 impervious cover and 2005 withdrawals on 1981-2000 monthly mean flows for HUC watershed 03130001 - Upper Chattahoochee (Atlanta, GA area) (a), and HUC watershed 14010001 - Colorado Headwaters (Denver, CO area by interbasin transfer) (b). Error bars represent one standard deviation about the mean monthly flows when both impervious cover and withdrawal impacts were included.

the summer low flow months. For example, the mean July flow increased $29 \%\left(34 \mathrm{Mm}^{3} \mathrm{yr}^{-1}\right)$ as a result of impervious cover while mean February flow increased by $4.7 \%$ $\left(21 \mathrm{Mm}^{3} \mathrm{yr}^{-1}\right)$ (Fig. 6a). Net surface water withdrawals decreased mean annual flow by $1.7 \%\left(50 \mathrm{Mm}^{3} \mathrm{yr}^{-1}\right)$ and the decreases in flow were greatest in the summer months of high water use, decreasing monthly flow in July, August, and September approximately $3 \%\left(4 \mathrm{Mm}^{3} \mathrm{yr}^{-1}\right)$. The impervious cover more than offset the impact of withdrawals on river flow in this watershed resulting in a $9.4 \%\left(277 \mathrm{Mm}^{3} \mathrm{yr}^{-1}\right)$ increase in mean annual flow, with the largest impacts occurring in the summer low flow months.

The HUC watershed 14010001 - Colorado Headwaters lies on the western face of the Rocky Mountains, and serves as a water supply to many watersheds to the east by interbasin transfer, including the Denver, CO metropolitan area (Petsch Jr., 1985). This watershed is downstream of two other HUC watersheds, the combined drainage area over the three watersheds was $54 \%$ forested, with only $0.7 \%$ of the watershed area in impervious cover. Net surface water withdrawals over the three watersheds in the drainage area were $129 \mathrm{Mm}^{3} \mathrm{yr}^{-1}$. River flow in this watershed peaked in late spring and early summer, driven by snow accumulation and melt processes (Fig. 6b). Impervious cover had a minimal effect on mean annual flow $\left(0.7 \%\right.$ increase, or $\left.28 \mathrm{Mm}^{3} \mathrm{yr}^{-1}\right)$, and on monthly river flow through much of the year, except in the early spring (Fig. 6b) when river flows were low resulting in large relative but small absolute increases in flow (e.g., $18 \%$ relative change, $1.4 \mathrm{Mm}^{3} \mathrm{yr}^{-1}$ absolute change in March). Net surface water withdrawals decreased mean annual river flows by $3.3 \%\left(129 \mathrm{Mm}^{3} \mathrm{yr}^{-1}\right)$, and most of this decrease was a result of decreases during the summer months.

\subsection{Impacts of future changes in impervious cover, withdrawals, and climate on river flows}

The impacts of projected changes in impervious cover, water withdrawals, and climate on river flows by 2060 were evaluated by comparing the following scenarios to the 2010 impervious cover, 2005 water withdrawals, and 1981-2000 climate baseline case: (1) 2060 impervious cover, 2005 withdrawals, 1981-2000 climate, (2) 2010 impervious cover, 2060 withdrawals, 1981-2000 climate, (3) 2010 impervious cover, 2005 withdrawals, 2041-2060 climate, and (4) 2060 impervious cover, 2060 withdrawals, 2041-2060 climate. Each scenario was evaluated using both the Low and High growth and emission scenarios.

\subsubsection{Impervious cover, withdrawals, and climate projections}

The HUC watershed population density in the US under baseline 2010 conditions was highest near major metropolitan areas, with a total population of approximately 310 million across the 2099 watersheds considered in this study. This total was projected to increase to 390 million (26\% increase) and 458 million (48\% increase) by 2060 
under the Low and High scenarios, respectively. Changes in population across the conterminous US were not uniform, rather some areas were projected to have decreases in population under both the Low and High scenarios (e.g., Maine, western Pennsylvania, Montana, and Wyoming) while other more urbanized areas were projected to have increases in population (e.g., much of the Atlantic seaboard, south Texas, and the Southwest).

The increases in population have direct implications for impervious cover and domestic water withdrawals. Because impervious cover did not decrease with decreasing population, the spatial patterns of increases in impervious cover were related only to patterns of population increases. In contrast, spatial patterns of domestic water use were related to both population increases and decreases. The total impervious area across the US by 2060 was projected to be approximately $117300 \mathrm{~km}^{2}$ under the Low scenario (increase of $15200 \mathrm{~km}^{2}$, or $\left.15 \%\right)$ and $128800 \mathrm{~km}^{2}$ under the High scenario (increase of $26700 \mathrm{~km}^{2}$, or $26 \%$ ). The additional demand for water resulting from population growth led to the same relative increases in total US domestic water use as the relative increases in population (26\% and $48 \%$, Low and High scenarios, respectively), but this increase in domestic water use led to small changes in total US water use across all sectors ( $2.3 \%$ Low and $4.2 \%$ High). The largest increases in total water use were in Texas (WRR 12; $8.5 \%$ Low, $13.4 \%$ High), Mid-Atlantic and Southeast coastal states (WRR 02 and WRR $03 ; 7.3 \%$ and $4.2 \%$ Low, $8.9 \%$ and $8.4 \%$ High, respectively), and the Southwest (WRR 13, 15, 16, 18; 3.8$5.7 \%$ Low, 6.6-12.1\% High). Despite the overall increases in domestic and total water use, more than $50 \%$ of the 2099 HUC watersheds were projected to experience decreases in water use as a result of decreases in population by as much as $28 \%$ and $43 \%$ under the Low and High scenarios, respectively.

Spatial patterns of changes in CM2.0 climate model projected mean annual precipitation and temperature between the 1981-2000 and 2041-2060 time periods under the Low and High scenarios were similar, but the magnitude of the changes were generally more severe under the High scenario. Under both scenarios, there were modest increases in precipitation across much of WRR 01-07, while WRR 08, 10-16, and 18 were projected to have decreases in precipitation. The mean annual precipitation averaged across all 2099 HUC watersheds of the US was projected to decrease from $789 \mathrm{~mm}$ in $1981-2000$ to $767 \mathrm{~mm}(2.8 \%)$ in $2041-2060$ under the Low scenario and to $778 \mathrm{~mm}(1.4 \%)$ under the High scenario. Mean annual temperature averaged across all watersheds was projected to increase from $11.3^{\circ} \mathrm{C}$ in $1981-2000$ to $13.1^{\circ} \mathrm{C}\left(+1.8^{\circ} \mathrm{C}\right)$ in $2041-2060$ under the Low scenario and to $13.8^{\circ} \mathrm{C}\left(+2.5^{\circ} \mathrm{C}\right)$ under the High scenario, with the largest increases in temperature projected to in Iowa, Kansas, Missouri, and Nebraska.

\subsubsection{Individual and combined impacts of 2060 impervious cover, withdrawals, and climate}

Increases in impervious cover by 2060 from 2010 levels resulted in minimal increases in mean annual flow $(<1 \%)$ in 1846 and 1699 of the 2099 HUC watersheds under the Low and High scenarios, respectively. Fifty-seven HUC watersheds located in southern California, Arizona, Colorado, Texas, Georgia, and Florida were projected to have changes in mean annual flow of more than $5 \%$ as a result of impervious cover change under the Low scenario, while 117 watersheds were projected to have more than $5 \%$ difference under the High scenario. Similarly, changes in withdrawals as a result of population change led to small differences in mean annual river flow (less than $1.0 \%$ difference) in 1972 HUC watersheds under the Low scenario, and 1903 watersheds under the High scenario. Thirty-nine HUC watersheds were projected to have decreases in mean annual flow of more than $5 \%$ under the Low scenario (87 watersheds under the High scenario), all of which were located in southern California, southern Nevada, Arizona, Colorado, New Mexico, and Texas. Changes in river flows as a result of climate change were much greater than those predicted as a result of increases in impervious cover and withdrawals from 2010 and 2005 levels, respectively. In contrast to the impacts of impervious cover and withdrawals, climate change impacts led to greater than $5 \%$ changes in river flows in 1677 HUC watersheds under the Low scenario, and 1735 watersheds under the High scenario. Relative changes in mean annual river flows across all HUC watersheds were positively correlated to relative changes in PPT between the time periods of 1981-2000 and 2041-2060 (Low scenario: $R^{2}=0.56$, $p<0.01$; High scenario: $\left.R^{2}=0.61, p<0.01\right)$ and negatively correlated to absolute changes in temperature (Low scenario: $R^{2}=0.27, p<0.01$; High scenario: $R^{2}=0.18, p<0.01$ ). The correlation between river flows and PPT was stronger (i.e., higher $R^{2}$ ) than the correlation of river flows with temperature, indicating that river flows are more responsive to PPT than temperature. McCabe and Wolock (2011) reported similar findings using historical climate and modeled runoff across the conterminous US.

The combined effects of future changes in impervious cover, withdrawals, and climate change were predicted to result in a mean decrease in river flows across all HUC watersheds in the conterminous US of $11.8 \%$ under the Low scenario and $11.0 \%$ under the High scenario (Fig. 7). Under the Low scenario, HUC watersheds in WRR 01-03 were predicted to have modest increases $(1.7-5.9 \%)$ in mean annual river flows on average, however mean annual flows in all other WRR were predicted to decrease up to $38 \%$ (WRR 11) by 2041-2060 (Fig. 7). Like the Low scenario, mean annual flows in WRR 01 and 02 were predicted to increase under the High scenario (6.6\% and $11 \%$, respectively), but also were predicted to increase in WRR $04(7.6 \%)$ and WRR 09 $(8.8 \%)$. All other WRR were predicted to have decreases in 


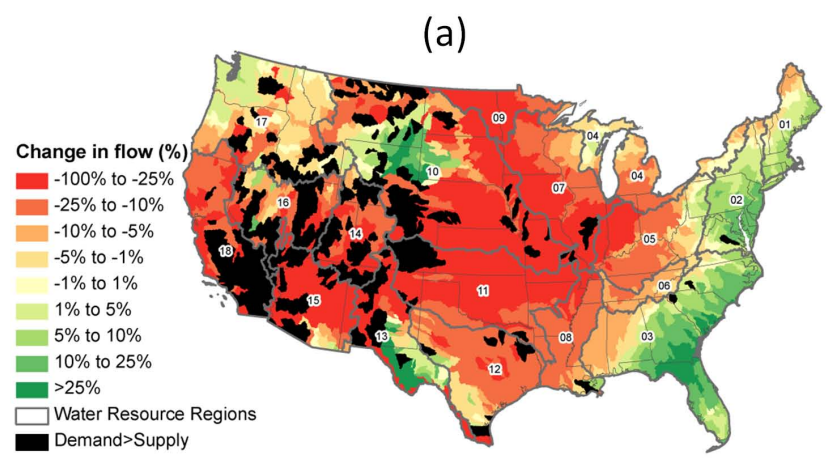

(b)

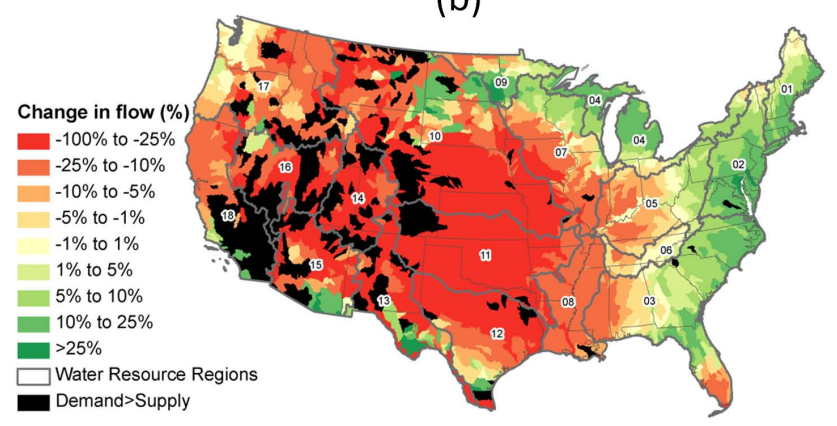

Fig. 7. Impact of impervious, population, and climate change on mean annual flow in 2060 for the Low (a) and High (b) growth and emission scenarios from the baseline case of 1981-2000 climate with 2005 water withdrawals and 2010 impervious cover. Gross demand in black areas is greater than the sum of surface water supply and groundwater withdrawals, indicating likely transfer of water from other watersheds.

mean annual flow up to $48 \%$ (WRR 11). In the 2010 baseline case, $186 \mathrm{HUC}$ watersheds were predicted to have mean annual WaSSI greater than 1.0 (Fig. 4d), indicating likely transfer of water from another watershed to meet current water demands. By 2060, the number of HUC watersheds with WaSSI greater than 1.0 increases to 248 under the Low scenario and 244 under the High scenario (Fig. 7), indicating that expansion of water transfer infrastructure would be required to meet projected water demand under future climate conditions. The extent of current and future interbasin transfers are likely underestimated because many watersheds with WaSSI values less than 1.0 receive water by interbasin transfer, but the data to determine whether they do does not exist at this scale.

\subsubsection{Case studies}

The case study HUC watersheds presented in Sect. 3.2.5 were examined to illustrate the potential watershed-level impacts of projected changes in impervious cover, withdrawals, and climate change. Impervious cover in HUC 03130001 Upper Chattahoochee River was projected to increase from
$10 \%$ of the total watershed area in 2010 to $17 \%$ (Low scenario) or $19 \%$ (High scenario) of the watershed area by 2060 . These changes in impervious cover were predicted to increase mean annual flow from this watershed by $6 \%$ (Low) or $9 \%$ (High). Net surface water withdrawals in this watershed as a result of population change was predicted to increase by $52 \%$ (Low) or $89 \%$ (High), resulting in a decrease in mean annual flow at the watershed outlet of $0.8 \%$ (Low) or $1.4 \%$ (High). Mean annual PPT was predicted to increase $1.9 \%$ (Low) or $4.2 \%$ (High), while mean annual temperatures were predicted to increase by $1.3^{\circ} \mathrm{C}$ (Low) or $2.1{ }^{\circ} \mathrm{C}$ (High), resulting in increases in PET of $10 \%$ (Low) or $15 \%$ (High). These changes in PPT and temperature resulted in virtually no change in mean annual flow (Low: $-0.2 \%$, High: $0.7 \%$ ). The combined effects of changes in impervious cover, withdrawals, and climate resulted in predicted increases in mean annual flow of $5.6 \%$ and $8.9 \%$ for the Low and High scenarios, respectively, driven largely by the increases in impervious cover. Similar to the 2010 baseline condition, the impact of increases in impervious cover were most pronounced during the summer low flow months (Fig. 8a). Despite the large relative increases in net surface water withdrawals projected for the Low and High scenarios, monthly river flows from this watershed were not impacted to a significant extent (less than $3 \%$ ) because these withdrawals were still small relative to the total river flow at the watershed outlet. Climate change impacts, while not significant on the annual scale, altered the timing of river flows, with predicted flow decreases of 14-24\% during March-August, and increases in September-January of $13-40 \%$. The flow decreases during the summer months were partially offset by the predicted flow increases as a result of increased impervious cover, which also led to increased river flows during the late fall and winter months.

HUC watershed 14010001 - Colorado Headwaters and the watersheds draining to it were projected to have impervious cover increase from $0.7 \%$ of the total watershed area in 2010 to $0.9 \%$ (Low) or $1.2 \%$ (High) by 2060, resulting in changes in mean annual flow from 2010 of less than $1.0 \%$ at the outlet of HUC 14010001. Net surface water withdrawals were predicted to increase $2 \%$ (Low) or $5 \%$ (High), again resulting in changes in mean annual flow of less than $1 \%$. The impact of climate change, however, was predicted to decrease mean annual flow by $22 \%$ (Low) or $25 \%$ (High), driven partly by reductions in mean annual PPT of $4.9 \%$ (Low) or $4.3 \%$ (High), but mostly because increases in temperature of $2.2^{\circ} \mathrm{C}$ (Low) or $2.9^{\circ} \mathrm{C}$ (High) resulted in PET increases of $18 \%$ (Low) or $24 \%$ (High). Because the impacts of changes in impervious cover and withdrawals were minimal in this watershed, the changes in mean annual flow as a result of the combined changes in impervious cover, withdrawals, and climate change were almost completely driven by the changes in climate. River flows in early spring months were predicted to increase under the High climate change scenario (Fig. 8b), however the peak spring flow was predicted to 
(a)
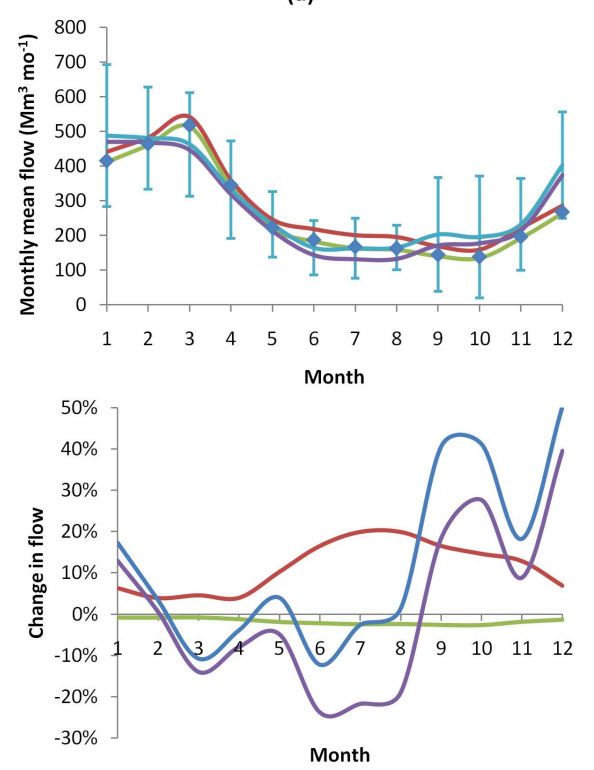

(b)
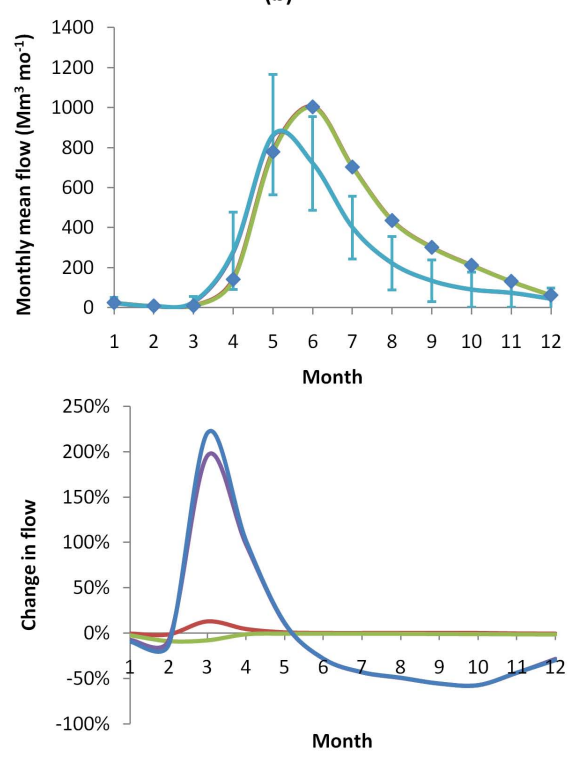

Fig. 8. Impacts of changes in impervious cover, withdrawals, and climate on monthly mean flows from 2010 levels by 2060 under the High growth and emission scenario for HUC watershed 03130001 - Upper Chattahoochee (Atlanta, GA area) (a), and HUC watershed 14010001 - Colorado Headwaters (Denver, CO area by interbasin transfer) (b). Error bars represent one standard deviation about the mean monthly flows when climate, impervious cover, and withdrawal impacts were included.

decrease $13 \%$ and to occur one month earlier, and flows during June-October were predicted to decrease $29-59 \%$. The increases in April-May flows occurred as a result of increased winter PPT $(13 \%)$, with a larger proportion falling as rain rather than falling and accumulating as snow as a result of the increased temperature. The peak flow decreased partly as a result of a temperature driven decrease in maximum spring snowpack ( $8 \%$ ), but also as a result of increased PET in early spring. Summer flows decreased under the A2 scenario as a result of a $20 \%$ decrease in June-July-August PPT, but also due to a $31 \%$ increase in PET.

\section{Discussion}

The uncalibrated WaSSI model reproduced observed spatial and temporal variability in river flows within relatively unregulated headwater watersheds, except in watersheds in arid regions and to a lesser extent in watersheds with extensive crop irrigation. Other continental scale water balance models, even those that were highly calibrated, have similar biases in these regions (e.g., Hay and McCabe, 2002; Martinez and Gupta, 2010; McCabe and Wolock, 2010). Clearly, future continental scale modeling research should focus on these regions through improving the representation of surface water-groundwater interaction and ET processes for large basins. Despite some region-specific issues, WaSSI appeared to be appropriately sensitive to both land cover and climate variability, and thus was well suited to investigate the relative impact of multiple elements of global change on river flows.
This study suggests that impervious cover at 2010 levels has increased river flows in watersheds draining major urban areas, and the influence of impervious cover may be felt far downstream. However, impervious cover has not had an appreciable effect on flows in most watersheds or on the nation as a whole at the 8-digit HUC watershed scale. Urban areas are typically much smaller than an 8-digit HUC watershed (mean $3750 \mathrm{~km}^{2}$ ), and thus the impacts of impervious cover are likely much greater at a finer spatial resolution (e.g., 12-digit HUC watershed; mean $95 \mathrm{~km}^{2}$ ) because a much larger proportion of smaller watersheds may be impervious. Although impervious cover increases river flows, it should not be considered as a management strategy for increasing water supply due to the negative impacts on aquatic habitat and water quality. The deleterious effects of impervious cover on water quality and flooding are well known, and resource managers in recent decades have required stormwater management strategies for new development and in some cases are requiring retrofits of management infrastructure for existing development. Past studies have shown that stream ecosystems in watersheds with $10 \%$ impervious cover or more were generally degraded (see Sun and Lockaby, 2012). Withdrawals have not significantly altered mean annual river flows at the 8-digit HUC watershed scale in most of the Eastern US (within $5 \%$ of flows without accounting for withdrawals), but have significantly decreased flows in the West. Like impervious cover, local impacts of withdrawals at a finer spatial resolution are likely more significant than at the scale of the 8-digit HUC. Water withdrawals in many watersheds 
in the West were greater than available supply, indicating that these watersheds likely receive water from other basins by interbasin transfer and/or have significant water storage in reservoirs. The Southwest region was most sensitive to changes in impervious cover and withdrawals on a relative basis because river flows in the Southwest are generally very low relative to more humid areas such as the Southeast.

By 2060, climate change impacts will dominate impervious cover and withdrawal impacts on river flow regardless of the global change scenario (e.g., Low or High). Under the CM2.0 climate projections for the Low and High scenarios, much of the Atlantic coast was projected to have minor increases in mean annual flow by 2060 , while most of the rest of the nation was projected to have decreases in mean annual flow, particularly across the Midwest and Great Plains regions. As a result, more watersheds were predicted to have water demand greater than available supply by 2060 than under the baseline 2010 condition. In areas where mean annual flow was not predicted to change as a result of climate change, the seasonal timing of flows changed considerably in some watersheds.

This study has many terrestrial and aquatic ecohydrological implications, as well as implications for the management of water resources for human use. Projected land conversion by 2060 from native forest, grassland, and shrubland to urban uses with the associated impervious cover will alter local water balances by reducing groundwater recharge and evapotranspiration, increasing surface runoff, and potentially altering regional temperature and precipitation patterns (Zhao et al., 2001). The impacts of urbanization and impervious cover on hydrology and stream ecosystems are well described in the literature (e.g. Scheuler, 1994, 2003; Paul and Meyer, 2001; Poff, 2006). These impacts include increased stormflow volumes and velocities that lead to streambank failure, bed scouring, channel incision, and a loss of connectivity with the floodplain, and decreased groundwater recharge that reduces or eliminates baseflow between storm events. These hydrologic factors degrade habitat and contribute to loss of aquatic biodiversity.

Parts of the arid and semi-arid Western US are known as the "bread basket" because much of the nation's food production occurs here, supported primarily by groundwater irrigation. The large predicted decreases in river flows in these drylands, coupled with declining groundwater supplies (see Dugan et al., 1994) may necessitate the relocation of agricultural production, the construction of new or expansion of existing interbasin transfer infrastructure, reduction of water demand through conservation, or some combination of these alternatives. Unfortunately, increasing arable land in order to provide food for an expanding global population under changing climate regimes has limited utility and comes at an environmental cost (Wang et al., 2012). In addition to human consequences, the predicted decreases in flow may significantly impact aquatic community structure through habitat reduction and fragmentation for fish and mussels (Xenopoulos and Lodge, 2006; Spooner et al., 2011). As the seasonal timing of river flows was predicted to change, management and/or design of existing storage reservoirs may need to be modified to account for these changes. In addition, predicted changes in timing and magnitude of river flows in snow-dominated watersheds of the mountainous Western US may significantly impact riparian vegetation and aquatic fauna (Yarnell et al., 2010).

The climate change impacts on river flows as well as the changes to infrastructure required to support human water needs will have an impact on existing human communities and downstream aquatic life, requiring a balanced approach to water resource management. In this study, we evaluated climate change using climate projections from a single global circulation model to illustrate the potential relative impact of climate, impervious cover, and withdrawal change by 2060 , and the impact of different emission scenarios. Our results suggest that climate change impacts will have a larger impact on river flows than either impervious cover or withdrawals at the national scale. Unfortunately, climate change is also the most uncertain of the global change drivers. Management of water resources in light of climate change should consider a range in projected futures to encapsulate the uncertainty in possible outcomes (Pierce et al., 2009; Mote et al., 2011). Facing the large uncertainty of climate change, efforts to continue to reduce uncertainties, re-evaluate past decisions in light of the changing climate, and identify the most effective policies based on the current scientific understanding will contribute to prudent water management.

Future work should include improvement in model representation of water withdrawals and storage in reservoirs at the national scale, as well as the socioeconomic drivers that impact water supply, demand, and use, and improvement in representation of the connectivity between surface and groundwater. In this study, we assumed vegetative landcover distribution and leaf area index were constant over time, however vegetation structure and function are influenced by climatic drivers. Future work should also focus on simulating regional vegetative response to climate change. Our results suggest that withdrawals may result in increases in river flows depending on the groundwater contribution to total withdrawals and return flow rates. Many studies suggest that groundwater withdrawals have decreased river flows across the Great Plains region (WRR 11 and 12) (see Kustu et al., 2010). Whether groundwater withdrawals increase or decrease river flows will depend on the extent to which the groundwater aquifer source is connected to surface water. Groundwater withdrawn from deep aquifers that are disconnected from surface water (i.e., groundwater mining) may increase river flows if return flows are discharged to surface water, while groundwater withdrawn by shallower unconfined aquifers that are connected to surface water may decrease river flows due to consumptive use. In this study we made several assumptions to account for groundwater withdrawals including (1) all withdrawals return to surface 
water, (2) there is no connection between groundwater withdrawals and the groundwater near the surface that impacts runoff and baseflow generation, and (3) there is no connection between shallow and deep groundwater sources. Modeling the connectivity of ground and surface water and the impact of groundwater withdrawals at the continental scale remains a challenge, and further refinement of modeling methods is needed to better represent their impact.

In addition to improvement in modeling approaches, improvement in water withdrawal databases are also warranted. The USGS water withdrawal estimates were not intended to be used to evaluate the impacts of withdrawals on river flow, however this dataset is the only source of water withdrawal information at the conterminous US scale. There is a clear need for quantitative, spatially explicit water withdrawal, use, and transfer information that a national water census could provide. The WaSSI model framework established in this study will be easily adapted to these data when they become available, providing improved estimation of withdrawal impacts on river flows.

\section{Conclusions}

The WaSSI water balance and flow routing model developed in this study is a powerful tool for examining the potential hydrologic response to future global change across the US. Our results show that global change impacts on water resources are watershed-specific. While climate change impacts overwhelmed the impacts of impervious cover and withdrawals on mean annual flows, impervious cover impacts may offset the impact of climate change during the growing season in some increasingly urbanized watersheds. In the Western US, large water withdrawals will aggravate the impact of climate change on river flows. It is important to evaluate the individual and combined impacts of impervious cover, water withdrawals, and climate change on historic river flows to develop future mitigation and adaptation management options for global change. Future hydrologic changes have important ecohydrological implications for local watersheds including alteration of the terrestrial water balance, stream channel habitat modification, fish and mussel extirpation, and alteration of riparian and aquatic community structure in snowdominated basins. In addition, there are implications for anthropogenic water management including new infrastructure requirements to support increasing demand for water, relocation of agricultural production, and/or water conservation measures.
Acknowledgements. This work was supported by the USDA Forest Service Eastern Forest Environmental Threat Assessment Center, and National Science Foundation grant Decadal and Regional Climate Prediction using Earth System Models (EaSM), program solicitation NSF 10-554 (Award no. 1049200). We also wish to thank Victor Koren of the NOAA National Weather Service for providing SAC-SMA soil parameter input data, and the two anonymous reviewers and editor whose comments improved the quality and scientific impact of this manuscript.

Edited by: L. Wang

\section{References}

Alcamo, J., Döll, P., Henrichs, T., Kaspar, F, Lehner, B., Rösch, T., and Siebert, S.: Global estimates of water withdrawals and availability under current and future "business-as-usual" conditions, Hydrolog. Sci. J., 48, 339348, doi:10.1623/hysj.48.3.339.45278, 2003.

Anderson, R. M., Koren, V., and Reed, S.: Using SSURGO data to improve Sacramento Model a priori parameter estimates, J. Hydrol., 320, 103-116, doi:10.1016/j.jhydrol.2005.07.020, 2006.

Arnell, N. W.: Climate change and global water resources, Global Environ. Change, 9, S31-S49, doi:10.1016/S09593780(99)00017-5, 1999.

Averyt, K., Fisher, J., Huber-Lee, A., Lewis, A., Macknick, J., Madden, N., Rogers, J., and Tellinghuisen, S.: Freshwater use by U.S. power plants: Electricity's thirst for a precious resource, A report of the Energy and Water in a Warming World initiative, Union of Concerned Scientists, Cambridge, MA, 2011.

Bates, B. C., Kundzewicz, Z. W., Wu, S., and Palutikof, J. P. (Eds.): Climate Change and Water. Technical Paper of the Intergovernmental Panel on Climate Change, IPCC Secretariat, Geneva, 2008.

Biemans, H., Haddeland, I., Kabat, P., Ludwig, F., Hutjes, R. W. A., Heinke, J., von Bloh, W., and Gerten, D.: Impact of reservoirs on river discharge and irrigation water supply during the 20th century, Water Resour. Res., 47, W03509, doi:10.1029/2009WR008929, 2011.

Bierwagen, B. G., Theobald, D. M., Pyke, C. R., Choate, A., Groth, P., Thomas, J. V., and Morefield, P.: National housing and impervious surface scenarios for integrated climate impact assessments, P. Natl. Acad. Sci. USA, 107, 20887-20892, doi:10.1073/pnas.1002096107, 2010.

Burnash, R. J. C.: The NWS river forecast system - catchment modeling, in: Computer models of watershed hydrology, edited by: Singh, V. P., Water Resources Publications, Littleton, Colorado, 311-366, 1995.

Burnash, R. J. C., Ferral, R. L., and McGuire, R. A.: A generalized streamflow simulation system - Conceptual modeling for digital computers, Technical Report, Joint Federal and State River Forecast Center, US National Weather Service and California Department of Water Resources, Sacramento, California, p. 204, 1973.

Caldwell, P., Sun, G., McNulty, S., Cohen, E., and Moore Myers, J.: Modeling Impacts of Environmental Change on Ecosystem Services across the Conterminous United States, in Proceedings of the fourth interagency conference on research in the watersheds, Fairbanks, Alaska, 26-30 September 2011, 63-69, 2011. 
Carlisle, D. M., Wolock, D. M., and Meador, M. R.: Alteration of streamflow magnitudes, and potential ecological consequences: A multiregional assessment, Front. Ecol. Environ., 9, 264-270, doi:10.1890/100053, 2011.

Daly, C., Neilson, R. P., and Phillips, D. L.: A statisticaltopographic model for mapping climatological precipitation over mountainous terrain, J. Appl. Meteorol., 33, 140-158, doi:10.1175/1520-0450(1994)033<0140:ASTMFM>2.0.CO;2, 1994.

Döll, P., Fiedler, K., and Zhang, J.: Global-scale analysis of river flow alterations due to water withdrawals and reservoirs, Hydrol. Earth Syst. Sci., 13, 2413-2432, doi:10.5194/hess-13-24132009, 2009.

Dudgeon, D., Arthington, A. H., Gessner, M. O., Kawabata Z.-I., Knowler, D. J., L'ev^eque, C., Naiman, R. J., Prieur-Richard, A.H., Soto, D., Stiassny, M. L. J., and Sullivan, C. A.: Freshwater biodiversity: importance, threats, status and conservation challenges, Biol. Rev., 81, 163-182, 2006.

Dugan, J. T., McGrath, T. J., and Zelt, R. B.: Water-level changes in the High Plains aquifer-predevelopment to 1992, US Geological Survey Water-Resources Investigations Report 94-4027, US Geological Survey, Lincoln, Nebraska, 1994.

Fry, J., Xian, G., Jin, S., Dewitz, J., Homer, C., Yang, L., Barnes, C., Herold, N., and Wickham, J.: Completion of the 2006 National Land Cover Database for the Conterminous United States, Photogramm. Eng. Remote S., 77, 858-864, 2011.

Gerten, D., Rost, S., von Blo, W., and Lucht, W.: Causes of change in 20th century global river discharge, Geophys. Res. Lett., 35, L20405, doi:10.1029/2008GL035258, 2008.

Graf, W. L.: Dam nation: a geographic census of American dams and their large-scale hydrologic impacts, Water Resour. Res., 35, 1305-1311, 1999.

Hamon, W. R.: Computation of direct runoff amounts from storm rainfall, Int. Assoc. Sci. Hydrol. Pub., 63, 52-62, 1963.

Hay, L. E. and McCabe, G. J.: Spatial variability in waterbalance model performance in the conterminous United States, J. Am. Water Resour. Assoc., 38, 847-860, doi:10.1111/j.17521688.2002.tb01001.x, 2002.

Jackson, R. B., Carpenter, S. R., Dahm, C. N., McKnight, D. M., Naiman, R. J., Postel, S. L., and Running, S. W.: Water in a changing world, Ecol. Appl., 11, 1027-1045, 2001.

Karl, T. R., Melillo, J. M., and Peterson, T. C. (Eds.): Global Climate Change Impacts in the United States. Cambridge University Press, New York, 2009.

Kenny, J. F., Barber, N. L., Hutson, S. S., Linsey, K. S., Lovelace, J. K., and Maupin, M. A.: Estimated use of water in the United States in 2005, US Geological Survey Circular 1344, US Geological Survey, Reston, Virginia, p. 52, 2009.

Koren, V., Smith, M., and Duan, Q.: Use of a priori parameter estimates in the derivation of spatially consistent parameter sets of rainfall-runoff models, in: Calibration of Watershed Models Water Science and Applications, vol. 6, edited by: Duan, Q., Sorooshian, S., Gupta, H., Rosseau, H., and Turcotte, H., AGU, Washington, D.C., 239-254, 2003.

Koren, V., Moreda, F., Reed, S., Smith, M., and Zhang, Z.: Evaluation of a grid-based distributed hydrological model over a large area, paper presented at the 7th IAHS Scientific Assembly, Foz do Iguaçu, Brazil, 2005.
Kustu, M. D., Fan, Y., and Robock, A.: Large-scale water cycle perturbation due to irrigation pumping in the US High Plains: A synthesis of observed streamflow changes, J. Hydrol., 390, 222244, doi:10.1016/j.jhydrol.2010.06.045, 2010.

Lockaby, G., Nagy, C., Vose, J. M., Ford, C. R., Sun, G., McNulty, S., Caldwell, P., Cohen, E., and Moore Myers, J. A.: Water and Forests, in: The Southern Forest Futures Project: Technical Report, edited by: Wear, D. N. and Greis, J. G., USDA Forest Service, Southern Research Station, General Technical Report, Asheville, NC, 2011.

Lull, H. W. and Sopper, W. E.: Hydrologic effects from urbanization of forested watersheds in the Northeast, USDA Forest Service research paper NE-146, Northeastern Forest Experiment Station, USDA Forest Service, Upper Darby, Pennsylvania, 1969.

Marion, D. A., Sun, G., Caldwell, P. V., Ford, C. R., Ouyang, Y., Amatya, D. M., Clinton, B. D., Conrads, P. A., Gull-Laird, S., Dai, Z., Clingenpeel, J. A., Liu, Y., Roehl, E. A., Moore Meyers, J. A., and Trettin, C.: Managing Forest Water Quantity and Quality Under Climate Change in the Southern U.S., in: Climate Change Adaptation and Mitigation Management Options, edited by: Vose, J., CRC Press, Boca Raton, Florida, in press, 2012.

Martinez, G. F. and Gupta, H. V.: Toward improved identification of hydrological models: A diagnostic evaluation of the "abcd" monthly water balance model for the conterminous United States, Water Resour. Res., 46, W08507, doi:10.1029/2009WR008294, 2010.

McCabe, G. J. and Markstrom, S. L.: A monthly water-balance model driven by a graphical user interface, US Geological Survey Open-File report 2007-1088, US Geological Survey, Reston, Virginia, p. 6, 2007.

McCabe, G. J. and Wolock, D. M.: Future snowpack conditions in the western United States derived from general circulation model climate simulations, J. Am. Water Resour. Assoc., 35, 14731484, doi:10.1111/j.1752-1688.1999.tb04231.x, 1999.

McCabe, G. J. and Wolock, D. M.: Century-scale variability in global annual runoff examined using a water balance model, J. Climatol., 31, 1739-1748, doi:10.1002/joc.2198, 2010.

McCabe, G. J. and Wolock, D. M.: Independent effects of temperature and precipitation on modelled runoff in the conterminous United States, Water Resour. Res., 47, W11522, doi:10.1029/2011WR010630, 2011.

Meehl, G. A., Covey, C., Delworth, T., Latif, M., McAvaney, B., Mitchell, J. F. B., Stouffer, R. J., and Taylor, K. E.: The WCRP CMIP3 multi-model dataset: A new era in climate change research, B. Am. Meteorol. Soc., 88, 1383-1394, 2007.

Milly, P. C. D., Betancourt, J., Falkenmark, M., Hirsch, R. M., Kundzewicz, Z. W., Lettenmaier, D. P., and Stouffer, R. J.: Stationarity is dead: Whither water management?, Science, 319, 573-574, doi:10.1126/science.1151915, 2008.

Mote P., Brekke, L., Duffy, P. B., and Maurer, E.: Guidelines for constructing climate scenarios, EOS Trans. AGU, 92, 257-258, 2011.

Nakicenovic, N. and Swart, R. (Eds.): Emission scenarios, Cambridge University Press, UK, 2000.

National Hydrography Dataset: http://nhd.usgs.gov/index.html, last access: July 2010. 
Natural Resources Conservation Service, United States Department of Agriculture, US General Soil Map (STATSGO2), available online at http://soildatamart.nrcs.usda.gov, last access: 2 February 2012.

O'Driscoll, M., Clinton, S., Jefferson, A., Manda, A., and McMillan, S.: Urbanization effects on watershed hydrology and instream processes in the southern United States, Water, 2, 605648; doi:10.3390/w2030605, 2010.

Paul, M. J. and Meyer, J. L.: Streams in the urban landscape, Annu. Rev. Ecol. Syst., 32, 333-365, 2001.

Petsch Jr., H. E.: Inventory of inter-basin transfers of water in the western conterminous United States, US Geological Survey Open-File Report 85-166, Lakewood, CO, 1985.

Piao, S., Friedlingstein, P., Ciasis, P., de Noblet-Ducoudre, N., Labata, D., and Zaehle, S.: Changes in climate and land use have a larger direct impact than rising $\mathrm{CO}_{2}$ on global river runoff trends, P. Natl. Acad. Sci., 104, 15242-15247, 2007.

Pierce, D. W., Barnett, T. P., Santer, B. D., and Gleckler, P. J.: Selecting global climate models for regional climate change studies, $\mathrm{P}$. Natl. Acad. Sci. USA, 106, 8441-8446, 2009.

Poff, N. L. and Zimmerman, J. K. H.: Ecological responses to altered flow regimes: a literature review to inform the science and management of environmental flows, Freshwater Biol., 55, 194205, 2010.

Poff, N. L., Bledsoe, B. P., and Cuhaciyan, C. O.: Hydrologic variation with land use across the contiguous United States: Geomorphic and ecological consequences for stream ecosystems, Geomorphology, 79, 264-285, 2006.

Poff, N. L., Olden, J. D., Merritt, D. M., and Pepin, D. M.: Homogenization of regional river dynamics by dams and global biodiversity implications, P. Natl. Acad. Sci. USA, 104, 5732-5737, 2007.

Praskievicz, S. and Chang, H.: A review of hydrological modelling of basin-scale climate change and urban development impacts, Prog. Phys. Geogr., 33, 650-671, doi:10.1177/0309133309348098, 2009.

PRISM Climate Group: http://www.prism.oregonstate.edu/, last access: July 2010.

Schueler, T. R.: The importance of imperviousness, Water. Protect. Tech., 1, 100-111, 1994.

Schueler, T. R.: Impacts of impervious cover on aquatic systems, Watershed Protection Research Monograph No. 1, Center for Watershed Protection, Ellicott City, MD, 2003.

Seaber, P. R., Kapinos, F. P., and Knapp, G. L.: Hydrologic Unit Maps, US Geol. Surv. Water Supply Paper 2294, US Geological Survey, Denver, Colorado, 1987.

Slack, J. R., Lumb, A. M., and Landwehr, J. M.: HydroClimatic Data Network (HCDN) streamflow data set, 18741988, US Geol. Surv. Water Resour. Invest. Rep. 93-4076, US Geological Survey, Reston, Virginia, 1993.

Solley, W. B., Pierce, R. R., and Perlman, H. A.: Estimated use of water in the United States in 1995, US Geological Survey Circular 1200, US Geological Survey, Denver, Colorado, 1998.

Spooner, D. E., Xenopoulos, M. A., Schneider, C., and Woolnough, D. A.: Coextirpation of host-affiliate relationships in rivers: the role of climate change, water withdrawal, and host-specificity, Global Change Biol., 17, 1720-1732, doi:10.1111/j.13652486.2010.02372.x, 2011.
Sun, G. and Lockaby, B. G.: Water quantity and quality at the urbanrural interface, in: Urban-Rural Interfaces: Linking People and Nature, edited by: Laband, D. N., Lockaby, B. G., and Zipperer, W., American Society of Agronomy, Crop Science Society of America, Soil Science Society of America, Madison, Wisconsin, 2012.

Sun, G., McNulty, S. G., Moore Myers, J. A., and Cohen, E. C.: Impacts of multiple stresses on water demand and supply across the southeastern United States, J. Am. Water Resour. Assoc., 44, 1441-1457, doi:10.1111/j.1752-1688.2008.00250.x, 2008.

Sun, G., Alstad, K., Chen, J., Chen, S., Ford, C. R., Lin, G., Lu, N., McNulty, S. G., Noormets, A., Vose, J. M., Wilske, B., Zeppel, M., Zhang, Y., and Zhang, Z.: A general predictive model for estimating monthly ecosystem evapotranspiration, Ecohydrology, 4, 245-255, doi::10.1002/eco.194, 2011a.

Sun, G., Caldwell, P., Noormets, A., Cohen, E., McNulty, S., Treasure, E., Domec, J. C., Mu, Q., Xiao, J., John, R., and Chen, J.: Upscaling key ecosystem functions across the conterminous United States by a water-centric ecosystem model, J. Geophys. Res., 116, G00J05, doi:10.1029/2010JG001573, 2011 b.

Thomson, A. M., Brown, R. A., Rosenberg, N. J., Srinivasan, R., and Cesar Izaurralde, R.: Climate change impacts for the conterminous USA: An integrated assessment, Part 4: Water resources, Climatic Change, 69, 67-88, doi:10.1007/s10584-005-3610-y, 2005.

US Environmental Protection Agency (EPA): Land-Use Scenarios: National-Scale Housing-Density Scenarios Consistent with Climate Change Storylines, Global Change Research Program, EPA/600/R-08/076F, National Center for Environmental Assessment, Washington, DC, 2009.

Verdin, K. L.: ISLSCP II HYDRO1k Elevation-derived Products, in: ISLSCP Initiative II Collection, edited by: Hall, F. G., Collatz, G., Meeson, B., Los, S., Brown de Colstoun, E., and Landis, D. Oak Ridge National Laboratory Distributed Active Archive Center, Oak Ridge, Tennessee, USA, doi:10.3334/ORNLDAAC/1007, 2011.

Vörösmarty, C. J., Green, P., Salisbury, J., and Lammers, R. B.: Global water resources: Vulnerability from climate change and population growth, Science, 289, 284-288, doi:10.1126/science.289.5477.284, 2000.

Wang, L., D’Odorico, P., Evans, J. P., Eldridge, D. J., McCabe, M. F., Caylor, K. K., and King, E. G.: Dryland ecohydrology and climate change: critical issues and technical advances, Hydrol. Earth Syst. Sci., 16, 2585-2603, doi:10.5194/hess-16-25852012, 2012.

Watershed Boundary Dataset: http://www.nrcs.usda.gov/wps/ portal/nrcs/main/national/water/watersheds/dataset, last access: July 2010.

Wisser, D., Fekete, B. M., Vörösmarty, C. J., and Schumann, A. H.: Reconstructing 20th century global hydrography: a contribution to the Global Terrestrial Network-Hydrology (GTN-H), Hydrol. Earth Syst. Sci., 14, 1-24, doi:10.5194/hess-14-1-2010, 2010.

Xenopoulos, M. A. and Lodge, D. M.: Going with the flow: Using species-discharge relationships to forecast losses in fish biodiversity, Ecology, 87, 1907-1914, 2006.

Yarnell, S. M., Viers, J. H., and Mount, J. F.: Ecology and management of the spring snowmelt recession, Bioscience, 60, 114-127, doi:10.1525/bio.2010.60.2.6, 2010. 
Zhao, M., Pitman, A. J., and Chase, T.: The impact of land cover change on the atmospheric circulation, Clim. Dynam., 17, 467477, 2001.
Zhao, M., Heinsch, F. A., Nemani, R. R., and Running, S. W.: Improvements of the MODIS terrestrial gross and net primary production global data set, Remote Sens. Environ., 95, 164-176, doi:10.1016/j.rse.2004.12.011, 2005. 